\title{
Flow and structure in a dendritic glacier with bedrock steps
}

\author{
HESTER JISKOOT, ${ }^{1}$ THOMAS A FOX, ${ }^{1}$ WESLEY VAN WYCHEN ${ }^{1,2}$ \\ ${ }^{1}$ Department of Geography, University of Lethbridge, Lethbridge, $A B$, Canada \\ ${ }^{2}$ Department of Geography, Environment and Geomatics, University of Ottawa, Ottawa, ON, Canada \\ Correspondence: Hester Jiskoot <hester.jiskoot@uleth.ca>
}

\begin{abstract}
We analyse ice flow and structural glaciology of Shackleton Glacier, a dendritic glacier with multiple icefalls in the Canadian Rockies. A major tributary-trunk junction allows us to investigate the potential of tributaries to alter trunk flow and structure, and the formation of bedrock steps at confluences. Multi-year velocity-stake data and structural glaciology up-glacier from the junction were assimilated with glacier-wide velocity derived from Radarsat-2 speckle tracking. Maximum flow speeds are $65 \mathrm{~m} \mathrm{a}^{-1}$ in the trunk and $175 \mathrm{~m} \mathrm{a}^{-1}$ in icefalls. Field and remote-sensing velocities are in good agreement, except where velocity gradients are high. Although compression occurs in the trunk up-glacier of the tributary entrance, glacier flux is steady state because flow speed increases at the junction due to the funnelling of trunk ice towards an icefall related to a bedrock step. Drawing on a published erosion model, we relate the heights of the step and the hanging valley to the relative fluxes of the tributary and trunk. It is the first time that an extant glacier is used to test and support such model. Our study elucidates the inherent complexity of tributary/trunk interactions and provides a conceptual model for trunk flow restriction by a tributary in surge-type glaciers.
\end{abstract}

KEYWORDS: glacier flow, glacier erosion, glacier surges, mountain glaciers, structural glaciology

\section{INTRODUCTION}

Glacier confluence and tributary/trunk interaction in dendritic glacier systems result in diagnostic stress fields at the flow confluence, potentially affecting ice dynamics in both flow units. The magnitude of flow interaction may be defined by the degree to which a tributary overrides, is confluent with, or is sheared by, the trunk glacier, which is hypothesised to depend on the relative size and flux of the flow units in combination with the confluence morphology (Kargel and others, 2005). While some flow and structural effects of tributary/trunk interactions have been studied in detail, the main focus has been on confluent flow units rather than on overriding, blocking, or bulging glaciers (e.g. Voigt, 1966; Anderton, 1973; Eyles and Rogerson, 1977; Gudmundsson, 1999; Quincey and others, 2009). Complex effects at flow junctions can include: changes in the direction of one or both flow units; an increase in ice flux downstream of the junction point with a downward vertical flow component at the junction resulting in enhanced bed erosion; a horizontal strain rate that is longitudinally extensive and transverse compressive; a complex vertical strain rate; and a change in the ice fabric at the confluence, or a change in subglacial hydrology (Hambrey and Müller, 1978; Gudmundsson and others, 1997; Gudmundsson, 1999; Fatland and others, 2003; Anderson and others, 2006). In the context of landscape development, tributarytrunk junctions can cause prominent steps in the trunk valley profile (Penck, 1905; Lewis, 1947; MacGregor and others, 2000; Amundson and Iverson, 2006; Anderson and others, 2006; Headley and others, 2012), in turn affecting ice flux and effective pressure variations. Related to this, basin-wide bedrock erosion is increased in glaciers with multiple tributaries (Hallet and others, 1996).

In settings where tributaries display different flow behaviour than their trunks, medial moraines are commonly distorted and often result in elongated-bulging or tearshaped moraines, which are an important diagnostic surface signature of past surging behaviour (Meier and Post, 1969; Glazovskiy, 1996). Because tributary and trunk flow may be blocked or enhanced by each other's relative activity, tributary/trunk interaction has been proposed to have a causal relationship to surge dynamics (Hattersley-Smith, 1969; Jiskoot and others, 2001; Kotlyakov and others, 2008; King and others, 2015; Paul, 2015). Indeed, both locally and globally surge-type glaciers tend to be more dendritic than normal glaciers (Jiskoot and others, 2003; Sevestre and Benn, 2015), and in some regions tributaries have a higher surge propensity than their trunks (Clarke and others, 1986; Hewitt, 2007). Although longitudinally compressive structural features upstream of tributary confluence regions have been suggested to indicate constriction to outflow impeding sudden surge initiation (King and others, 2015), no clear mechanism has been identified as of yet, and the mere presence or absence of tributaries does not increase surge propensity. A detailed study of the velocity structure of a non-surge-type glacier with a major tributarytrunk junction may help elucidate this problem.

An improved awareness of the structure, stress and ice flow in proximity to tributary-trunk confluences is needed to better understand the dynamics of and interactions within dendritic systems. This awareness would also help to understand atypical glacier response to climate change, as glaciers with stepwise profiles and tributarydetachment-related fragmentation tend to respond nonlinearly to climate change (Oerlemans, 1989; Jiskoot and others, 2009).

The objective of our study is to quantify the structural glaciology and ice flow at the junction between a tributary and the trunk of Shackleton Glacier, Canadian Rockies. In doing so, we seek to: 
(A) Use an extant glacier to provide field evidence for the configuration of a hanging valley and bedrock step, and measured ice flux data, to test a published erosion model (MacGregor and others, 2000). This erosion model predicts, as a result of erosion rate scaling with sliding velocity: (i) a direct relationship between trunk valley step height and the ratio of tributary to trunk glacier discharge $\left(Q_{\text {trib }} / Q_{\text {trunk }}\right)$ and (ii) an inverse relationship between tributary hanging valley height and $Q_{\text {trib }} / Q_{\text {trunk, }}$ and thus an increase in hang height of small tributaries with distance down a trunk valley. The model was tested by Amundson and Iverson (2006), who used a simple erosion rule assuming that sliding velocity is proportional to balance velocity, which they estimated from balance discharge approximated from deglaciated valley morphology of former glaciers in hanging valleys feeding three trunk valleys on the eastern slopes of the Canadian Rockies. Their study found an agreement with both hypotheses from MacGregor and others (2000), but since a coarse approximation of $Q_{\text {trib }} / Q_{\text {trunk }}$ was used, a test using an extant glacier would add confidence in the model predictions, and may provide new insights into flow interaction and erosional processes at a tributary-trunk confluence.

(B) Better understand outflow restrictions in quiescent surge-type glaciers by identifying the potential of a bulging tributary to affect the flow of its trunk in a non-surge-type glacier. During quiescence, outflow restrictions in surge-type glaciers may cause significant deceleration, longitudinal compression and damming of upstream ice, enabling a reservoir zone to fill, thicken and steepen. When this zone reaches its critical basal shear stress a surge may be triggered, usually through a hydrological or soft bed failure mechanism (Raymond, 1987; Harrison and Post, 2003). Where subglacial water discharge is restricted, surging can be triggered in locations of high effective pressure or large pressure gradients (Murray and others, 2000; Fatland and others, 2003; Flowers and others, 2011). Outflow restrictions may have a range of causes, including a frozen base (Clarke and others, 1984), valley curvature (Echelmeyer and others, 1987; King and others, 2015), bedrock undulations (Flowers and others, 2011) or tributaries. Observations of confluencing flow units in surgetype glaciers suggest that trunk outflow restrictions tend to occur at near-right-angle junctions of flow units equivalent in size (i.e. cross-sectional area differences between tributary and trunk $<3$ ), and where no icefall occurs right below the junction (e.g. Black Rapids Glacier: Heinrichs and others, 1996; Shugar and others, 2010; Sortebrae: Jiskoot and others, 2001; Skamri and Drenmang Glaciers: Copland and others, 2009; Comfortlessbreen: King and others, 2015). Where confluence angles are more acute, the ice flows faster at and below the junction and remains aligned to the trunk flow, and where trunks and tributaries are separated by a subglacial bedrock ridge little flow interaction may occur (Davis and others, 1973; Gudmundsson, 1999; Satyabala, 2016). Combining these observations with our study of the non-surgetype Shackleton Glacier, we hypothesise that outflow restriction in a trunk by a tributary most likely occurs where no substantial bedrock step exists directly below a tributary-junction and where the tributary flux is at least one third of the trunk flux $\left(Q_{\text {trib }} / Q_{\text {trunk }}>0.3\right)$. Since MacGregor and others (2000) suggest that $Q_{\text {trib }} / Q_{\text {trunk }}>0.3$ likely results in a significant bedrock step, we further postulate that trunk discharge restriction by a tributary in surge-type glaciers may primarily occur where subglacial erosion is reduced or where structural controls prevent step formation. We then elaborate on possible glacial and geological conditions that suppress erosion.

\section{STUDY REGION}

Shackleton Glacier $\left(52^{\circ} 10^{\prime} \mathrm{N} ; 117^{\circ} 52^{\prime} \mathrm{W}\right.$ : Fig. 1$)$ is a $40 \mathrm{~km}^{2}$ temperate non-surge-type valley glacier that drains from the western slopes of the Canadian Rockies into the Upper Columbia River Basin (UCRB) (Jiskoot and others, 2009; Jiskoot and Mueller, 2012). It is the largest outlet glacier of Clemenceau Icefield $\left(271 \mathrm{~km}^{2}\right)$ and the largest glacier in the Canadian Rockies. Glaciological studies in the UCRB did not start until the 21st century (Ommanney, 2002) and glacier-wide remote-sensing-based ice flow measurements only exist for one glacier in the entire Canadian Rockies (Mattar and others, 1998). Clemenceau-Chaba icefield glaciers as a whole have diminished $14-28 \%$ in area since the 1980s (Jiskoot and others, 2009; Tennant and others, 2012). Shackleton Glacier has retreated $3.7 \mathrm{~km}$ since the Little Ice Age, with an average retreat rate of $40 \mathrm{~m} \mathrm{a}^{-1}$ since 1985. Glaciers that fragmented due to tributary detachment since the Little Ice Age have undergone accelerated retreat (Jiskoot and others, 2009). Shackleton Glacier experienced consistently negative mass balance between 2005 and 2010 , with ablation rates between 2.0 and $4.5 \mathrm{~m}$ w.e. $\mathrm{a}^{-1}$ in the mid ablation zone and a net annual ablation in the order of $38-50$ million $\mathrm{m}^{3}$ w.e. The glacier provides $\sim 1 \%$ of the UCRB run-off in August, while, collectively, glaciers contribute $20-35 \%$ of late-summer flow to its headwaters (Jiskoot and Mueller, 2012).

Shackleton Glacier is dendritic and has four flow units ranging in length from 7 to $10 \mathrm{~km}$ (Figs 1b, c). Each flow unit has top-heavy hypsometry and descends from an icefield zone (3000-2500 m a.s.l.) through icefalls to a mid-elevation valley zone (2300-1900 m a.s.l.: average slope $5^{\circ}$ ), through a lower icefall into a steep and narrow glacier tongue (1800$1300 \mathrm{~m}$ a.s.l.: average slope $15^{\circ}$ ). Three of the flow units coalesce to form the main trunk in the mid-elevation valley zone, where its flow is confined in a steep-sided mountain valley, in which the trunk width gradually narrows from 2 $\mathrm{km}$ to $\sim 50 \mathrm{~m}$ at the terminus. The fourth flow unit is a large tributary that enters the trunk at a right angle as an icefall, $\sim 2.5 \mathrm{~km}$ up-glacier from the terminus position in the year 2000 (Figs 1, 2). This last tributary-trunk junction is the one under investigation.

Shackleton Glacier is suitable to test both the erosion model hypotheses by MacGregor and others (2000) and potential controls on trunk outflow restrictions by a tributary, for the following reasons:

i. The glacier is relatively large, has a major bulging tributary that enters the trunk under a near right-angle (Figs 1,2), but is non-surge-type so no substantial outflow restriction is expected.

ii. It has a significant hanging valley step height and bedrock step height below the confluence. 


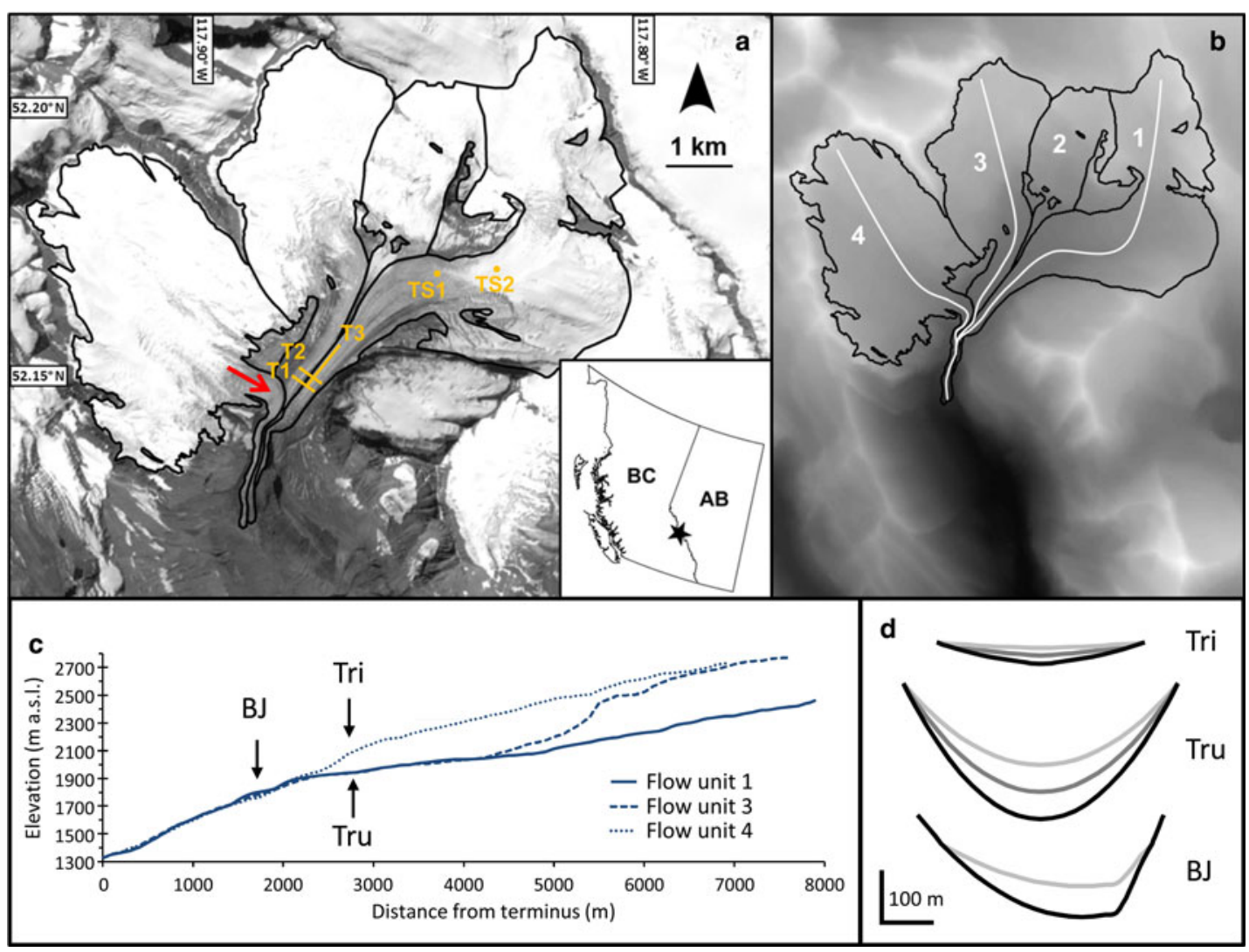

Fig. 1. (a) Shackleton Glacier outline on a Landsat 7 scene of 17 August 2000. The red arrow shows the tributary-trunk confluence, and in orange are the locations of the stake transects (T1-T3) and top stakes (TS1; TS2). The star on the inset map shows the glacier's location on the Rocky Mountains continental divide between the Canadian provinces of British Columbia and Alberta. (b) Shackleton Glacier's four flow units. Flow unit 2 terminates when it becomes incorporated in the medial moraine zone of flow units 1 and 3 (trunk). Flow unit 4 is the tributary. The background hillshaded DEM (Jiskoot and others, 2009) ranges from white on mountain peaks and ridges (2500-3417 m a.s.l.) to black in the valley floor (1000-1100 m a.s.l.). (c) Surface elevation profiles of the lower $8 \mathrm{~km}$ of flow units 1, 3 and 4. (d) Cross valley bed geometry of fluxgates in the trunk (Tru), tributary (Tri) and below the junction (BJ), inferred from various centreline thickness scenarios (Section 3.1.3). No vertical exaggeration. Fluxgate locations in Figures 1c, 3a.

iii. Its flow unit basins are confined by steep bedrock morphology with summits at elevations of 3000-3300 $\mathrm{m}$ a.s.l. These were likely nunataks during large periods of Pleistocene glaciation in the Canadian Cordillera (Jackson and Clague, 1991; Seguinot and others, 2016). Relative basin size therefore remained comparable over multiple Late Quaternary glaciations, which is an important assumption for testing the erosion model hypotheses.

iv. The underlying geological transition in the Middle Cambrian metasedimentary lithology along the step profile suggests that the lower strata (Eldon Formation: massive dolomite-mottled limestone; Pika Formation: dense grey limestone with minor dolomite and shale) are more resistant than the upper strata (Arctomys Formation: folded orange-weathering shale, interbedded with dolomitic siltstone and dolomite) (Lickorish, 1993; see Fig. 2a). Structurally, these lithologies form part of a northeast-dipping limb of an eroded syncline with the fold axis near T3 (Fig. 1), while no active faults underlie the glacier (Lickorish and others, 1992). Neither lithology nor structural geology would generate a strong pattern of erosion in and of itself, making the site an appropriate candidate for the MacGregor model, in which erosivity of the landscape is assumed uniform.

\section{METHODS}

As it is rare for structural features to accurately reflect local stresses and strain rates due to complex histories of deformation (van der Veen, 1999; Lawson and others, 2000), and crevasse development may be too weak to reflect measured erratic strain rates at a tributary-trunk junction (Hambrey and Müller, 1978), we use a combination of ice flow and structural glaciology measurements at different scales, and combine these with glacier geometry and elevation, to elucidate the ice flow patterns in Shackleton Glacier with a focus on the flow interaction at a bulging tributary-trunk junction.

\subsection{Surface flow velocity}

\subsubsection{Field measurements}

Surface velocities were calculated from the yearly displacement of 27 ablation stakes, measured in five July/August field campaigns in the years 2006-10, which are the same stakes as reported in Jiskoot and Mueller (2012). The bamboo stakes were configured in two transverse transects (T1 lower, T2 upper) of $450 \mathrm{~m}$ length, and one longitudinal transect (T3) of $800 \mathrm{~m}$ length parallel to ice flow of Shackleton's trunk upstream of the main tributary (Fig. 1). Transverse transects $\mathrm{T} 1$ and $\mathrm{T} 2$ each had 10 stakes spaced at $50 \pm 0.05 \mathrm{~m}$ intervals, and T3 had nine stakes spaced at 


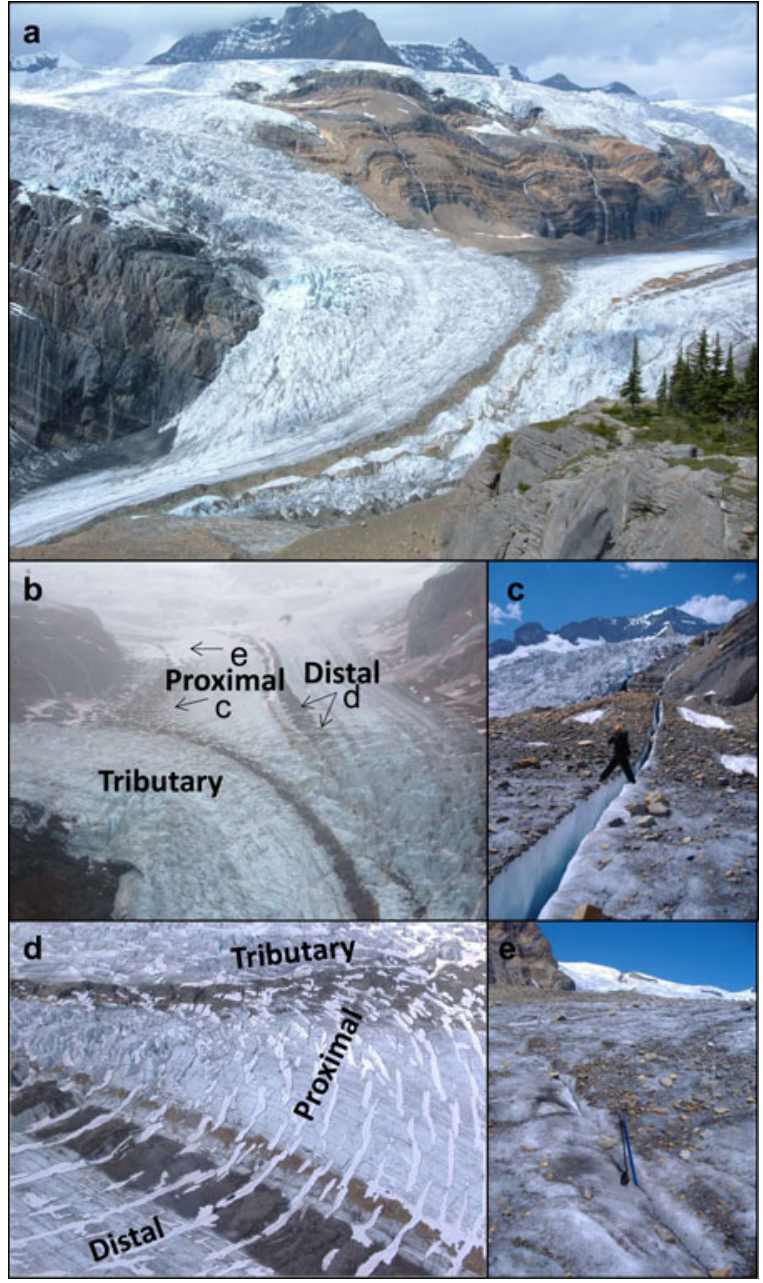

Fig. 2. Photos of Shackleton Glacier taken by $\mathrm{HJ}$ in the last week of July in the period 2005-10. Trunk glacier flow is from right to left in all photos but b, where flow is towards the viewer: (a) Flow unit 4 tributary (top) entering the trunk through an icefall. The trunk upstream of the tributary is $\sim 800 \mathrm{~m}$ wide. The folded metasedimentary bedrock is of Cambrian age: the upper strata (orange-weathering) are shale interbedded with dolomitic siltstone and dolomite, and the lower strata (grey) are limestone with minor dolomite and shale. (b) Detail of region upglacier of the tributarytrunk junction, with the arrows and letters indicating the perspective in photos c-e. (c) Taking crevasse dip measurements with tributary icefall in the background. (d) Medial moraines and snow-filled transverse crevasse patterns at the flow junction. (e) Thrust fault $\sim 1 \mathrm{~km}$ upstream of the flow junction. Supraglacial fountain near this location was observed in two field seasons.

intervals of $100 \pm 0.05 \mathrm{~m}$ within $5 \mathrm{~m}$ of the medial moraine on the distal side of the tributary. T1 and T2 cross T3 at its lowest and second lowest stake, respectively, $\sim 200$ and $300 \mathrm{~m}$ up-glacier from the tributary-trunk junction. The three transects were initially installed in straight lines, spanning an elevation range of 1890-1970 $\mathrm{m}$ a.s.l., and were resurveyed each year using a surveying total station (SOKKIA, Canada, SET 4110R with data collectors SDR33/8100). Surveying by total station was necessary due to the steeply incised glacier valley preventing sufficient satellite coverage for conducting survey-grade differential GPS measurements. Additionally, handheld GPS coordinates of the stake locations were recorded with a Garmin eTrex (4 m horizontal accuracy) or Garmin eTrex Legend HCx (3 m accuracy). Two 'top-stakes' (TS1; TS2: Fig. 1) in the upper ablation zone, $\sim 2.5$ and $3.5 \mathrm{~km}$ upstream of the highest T3 stake, were measured yearly by handheld GPS only. Surveying measurements were used for ice flow data analysis, while GPS measurements were for mapping only.

Each summer in the last week of July, $4 \mathrm{~m}$ long sectioned bamboo stakes were re-drilled within $30 \mathrm{~cm}$ upstream of the previous years' using a Kovacs auger. Stakes were surveyed before and after re-drilling with the total station located on the medial moraine. Surveying coordinates were recorded in a metric grid, oriented with its Northing in the overall along-flow direction and its Easting in the across-flow direction. Four fixed points, on rock and lateral moraine along the distal (East) side of the glacier, were re-sectioned each year from the medial moraine, after which all transect stakes were surveyed. Taking into account the measured surveying error in the fixed points, and repeated stake measurements on the same day, the average surveying errors were $0.12 \pm 0.11$ $\mathrm{m}$. Overall surveying errors were generally $<20 \mathrm{~cm}$, which is negligible $(<1 \%)$ when compared with the 2006-10 average annual flow velocity of $26.5 \mathrm{~m} \mathrm{a}^{-1}$. Stake displacements were corrected to annual ice velocities $\left(\mathrm{m} \mathrm{a}^{-1}\right)$ using Eqn (1).

$$
\begin{aligned}
\text { Annual velocity }= & (\text { stake displacement }(\mathrm{m}) / \\
& (\text { elapsed time between surveys }) \times 365 .
\end{aligned}
$$

Ice surface velocities were graphed to determine differences between years, transects and the proximal and distal side of the glacier, which are separated by the medial moraine and designated relative to the tributary (Fig. 2).

\subsubsection{Speckle tracking}

To determine the surface ice motion for the entire Shackleton Glacier system we used a custom-written MATLAB ${ }^{\mathrm{TM}}$ speckle-tracking algorithm on a pair of Radarsat-2 Extrafine beam ( $\sim 4 \mathrm{~m}$ resolution) images acquired on 12 January and 4 February 2015 (24-day orbital separation). This code uses a cross-correlation algorithm on image chips $(400 \mathrm{~m}$ in both azimuth and range, $2300 \mathrm{~m}$ of overlap between adjacent image chips) to determine the relative displacement between scenes (Van Wychen and others, 2016). The 1: 250000 Canadian DEM (CDEM) was used to remove the range shift component from displacements which arises from varying geometry across the image swath (Van Wychen and others, 2016). To remove any systematic biases that arise from inaccuracies in the satellite baseline estimates or squint effects between image acquisitions, displacements were calibrated using areas of zero velocity (bedrock outcrops) and the determined biases in the range or azimuth shifts were then removed from the rest of the dataset and the displacements were standardised to annual values $\left(\mathrm{m} \mathrm{a}^{-1}\right)$ (Van Wychen and others, 2016).

Manual verification of the velocities was undertaken in ArcGISTM using the methodology of Van Wychen and others (2012); where (1) flow vectors should be constrained by topography and should be aligned with surface flow features (medial moraines); (2) velocities should be faster along the glacier centreline than near the margins due to lateral friction; and (3) adjacent flow vectors should show consistency in both the direction and magnitude of displacement. Identified mismatches were removed from the dataset and the velocities were then resampled to a $100 \mathrm{~m}^{2}$ resolution raster surface using an inverse distance weighting 

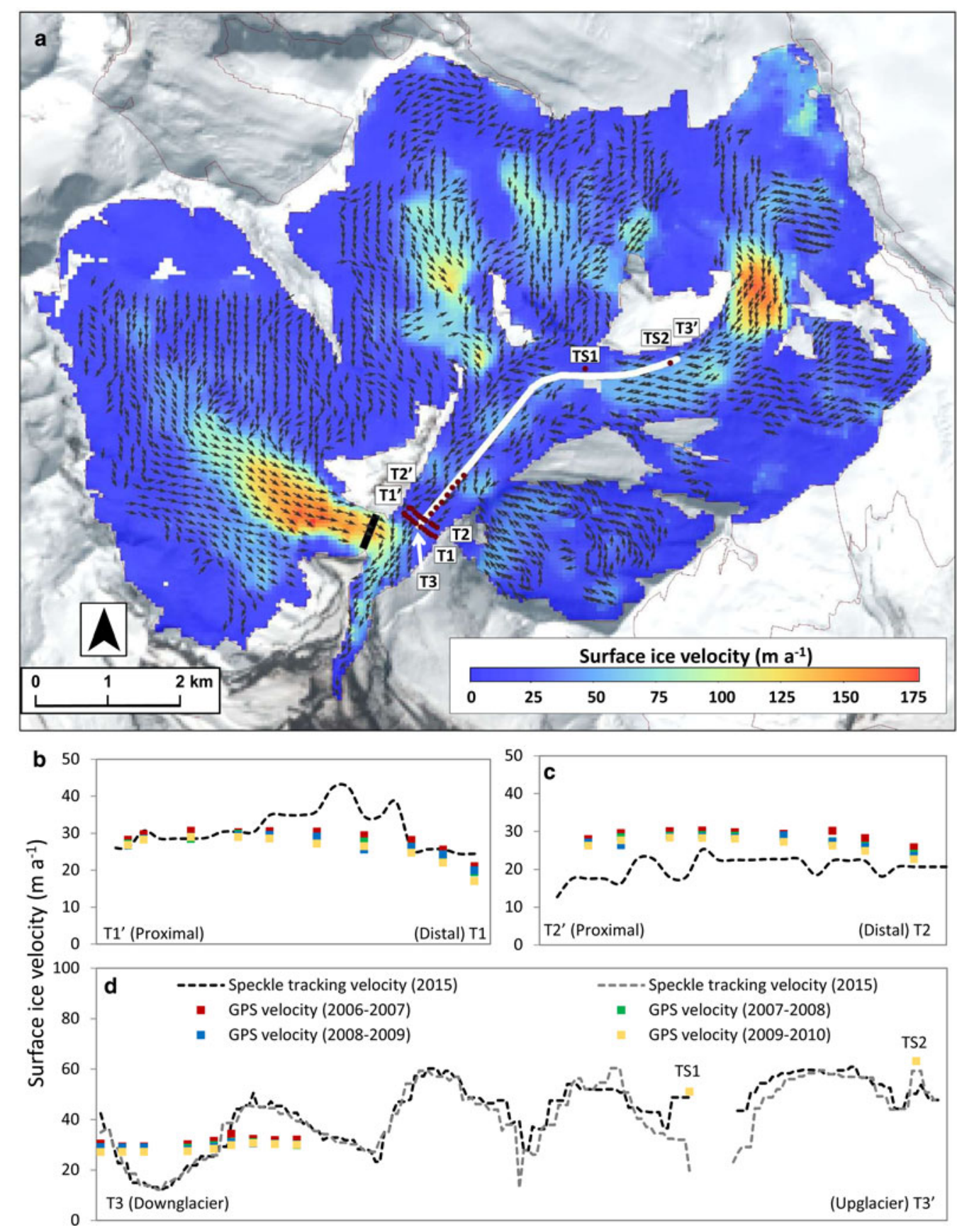

Fig. 3. (a) Velocity structure of Shackleton Glacier derived from Radarsat 2 speckle tracking. Speed is illustrated with colour shading, and flow direction with arrows (only for speeds $>15 \mathrm{~m} \mathrm{a}^{-1}$ ). Fluxgates across the tributary (black line) and trunk (T1 and T2) were used for flux calculations in Section 3.1.3. Velocity stakes (red dots) include positions of top stakes TS1 and TS2. (b-c) Flow speed along the transverse transects (T2 and T2) comparing speckle tracking results (line) with field measurements (coloured points). (d) Flow speed along the longitudinal transect (T3 white line in a), comparing speckle tracking (black and grey dotted lines) with field measurements (coloured points). The black and grey lines are parallel longitudinal transect lines with adjacent line centre-points, indicating the spatial sensitivity of Radarsat 2 speckle tracking velocities due to centroid averaging.

interpolation and clipped to the extent of the Shackleton Glacier basin. To provide an estimate of the confidence in our speckle tracking results we extract velocities over stationary features (bedrock outcrops and nunataks) and find an uncertainty estimate of $\sim \pm 13.6 \mathrm{~m} \mathrm{a}^{-1}(\mathrm{SD}=9.98)$ obtained from 180 000 point displacements (c.f. Van Wychen and others, 2012). Many of these points are in high topography areas with snow, whereas our region of interest contains crevasse features that can be tracked reliably and where GPS to speckle-tracking velocity differences are generally $<10 \mathrm{~m} \mathrm{a}^{-1}$. The likely maximum uncertainty for the glacier is therefore assumed to be $\pm 10 \mathrm{~m} \mathrm{a}^{-1}$.

\subsubsection{Trunk and tributary ice flux}

To find the ice flux contributions for the trunk and tributary, we determine the ice volume transferred through defined fluxgates at both locations (Fig. 3c). For the fluxgates we use a 'U-shaped' parabolic valley geometry, which is consistent with the modelling of valley glacier morphology after long periods of erosion (Harbor, 1992). The U-shaped morphology was modelled based on:

$$
\begin{aligned}
H_{\min / \mathrm{mid} / \max }= & \left(\left(20-C_{\min / \operatorname{mid} / \max }\right) / D_{1}^{2}\right) \times\left(D_{2}^{2}\right) \\
& +C_{\min / \operatorname{mid} / \max }
\end{aligned}
$$


where $H$ is the interpolated ice thickness using a parabolic interpolation from the assumed centreline ice thickness to an estimated marginal ice thickness of $50 \mathrm{~m}$ at the start and end stake of the trunk cross transects (see Section 3.1.1) and $10 \mathrm{~m}$ at the margins of the tributary fluxgate, $C_{\mathrm{min} / \mathrm{mid} / \mathrm{max}}$ is the scenario-based estimated centreline ice thickness (discussed below), $D_{1}$ is the horizontal distance from the glacier centreline to the margin and $D_{2}$ is the horizontal distance from the glacier centreline to the centre of the interpolated ice column. Ice columns were interpolated at $20 \mathrm{~m}$ from the centreline to the margins.

Due to the absence of ice thickness measurements on Shackleton Glacier, where summer surface conditions preclude use of ice radar, we adopt a scenario-based ice thickness approach. For the trunk flux gate we use minimum $\left(C_{\text {min }}: 200 \mathrm{~m}\right)$, midpoint $\left(C_{\text {mid }}: 250 \mathrm{~m}\right)$ and maximum $\left(C_{\max }\right.$ : $300 \mathrm{~m}$ ) as centreline ice thickness estimates, while for the tributary flux gate, at the top of an icefall, we use minimum $\left(C_{\text {min }}: 20 \mathrm{~m}\right)$, midpoint $\left(C_{\text {mid }}: 35 \mathrm{~m}\right)$ and maximum $\left(C_{\text {max }}\right.$ : $50 \mathrm{~m}$ ) centreline ice thickness. In the same manner we calculate the flux below the junction (BJ) through averaging of two fluxgates with minimum $\left(C_{\min }: 125 \mathrm{~m}\right)$, and maximum $\left(C_{\max }\right.$ : $180 \mathrm{~m})$ centreline ice thickness. See Figure $1 \mathrm{~d}$ for resulting valley geometries for all three locations.

Trunk centreline depths are estimated from depth ranges measured in comparable glaciers in the Canadian Rockies (Raymond, 1971; Ommanney, 2002) adjusted for thinning, and taking into account glacier catchment area and keyhole shaped geometry. This results in a relatively deep trunk valley as evidenced by the steep exposed valley walls. Tributary centreline depths are based on visual interpretation of the broad shallow icefall with séracs, in combination with maximum crevasse depths from the creep relation and measurements in temperate glaciers, and from the stability of a free standing ice cliff (Cuffey and Paterson, 2010; Colgan and others, 2016). See Section 3.1.4 for verification of all chosen scenarios.

Ice discharge flux $\left(Q_{\min / \operatorname{mid} / \max }\right)$ for the tributary and the trunk were calculated for each ice thickness scenario using the following equation:

$$
Q_{\min / \operatorname{mid} / \max }=a V \times W \times H_{\min / \operatorname{mid} / \max },
$$

where $V$ is the surface ice velocity $\left(\mathrm{m} \mathrm{a}^{-1}\right)$ at the centre of each ice column extracted from the raster surface of the speckle tracking results (see Section 3.2), dimensionless factor $a=0.8$ (trunk) or $a=0.9$ (tributary and below junction) is the depth-averaged velocity of the ice column (Cuffey and Paterson, 2010); $W$ is the uniform ice column width $(20 \mathrm{~m}) ; H_{\mathrm{min} / \mathrm{mid} / \max }$ are the depth scenarios $(m)$ for the fluxgates. Final $Q_{\min / \mathrm{mid} / \mathrm{max}}$ estimates for each cross section were then calculated from the sum of individual ice columns in units cubic metres per year.

\subsubsection{Verification of estimated ice thickness and flux} Estimated trunk and tributary centreline depth scenarios (tru$C_{\min / \mathrm{mid} / \mathrm{max}}: 200,250$ and $300 \mathrm{~m}$; tri- $C_{\min / \mathrm{mid} / \mathrm{max}}: 20,35$ and $50 \mathrm{~m}$ ), and ice fluxes (Table 1) were verified independently using established ice rheology and flow laws, modelled ice thickness and assumption of flux continuity. Although these methods require several assumptions, their combined results provide confidence that our depth scenarios are
Table 1. Trunk and tributary ice flux estimates for their three centre midpoint thickness $(C)$ scenarios

\begin{tabular}{lccc}
\hline $\begin{array}{l}\text { Trunk C } \\
\mathrm{m}\end{array}$ & $\begin{array}{l}\text { Trunk flux } 10^{6} \\
\mathrm{~m}^{3} \mathrm{a}^{-1}\end{array}$ & $\begin{array}{l}\text { Tributary C } \\
\mathrm{m}\end{array}$ & $\begin{array}{l}\text { Tributary flux } 10^{6} \\
\mathrm{~m}^{3} \mathrm{a}^{-1}\end{array}$ \\
\hline 200 & $1.52 \pm 0.57$ & 20 & $0.72 \pm 0.05$ \\
250 & $1.85 \pm 0.70$ & 35 & $1.12 \pm 0.08$ \\
300 & $2.19 \pm 0.82$ & 50 & $1.53 \pm 0.11$ \\
\hline
\end{tabular}

The trunk flux is averaged over two parabolic flux gates (Fig. 3: T1, T2). Uncertainties are based on the speckle-tracking velocity measurement uncertainty of $10 \mathrm{~m} \mathrm{a}^{-1}$.

appropriate, and within error ranges that would not significantly alter the overall conclusions drawn in this paper.

i. We calculated basal shear stress (Cuffey and Paterson, 2010: Eqn (8.90)) corresponding to the $C_{\min / \mathrm{mid} / \max }$ scenarios, using an ice density of $900 \mathrm{~kg} \mathrm{~m}^{-3}$, gravitational acceleration of $9.81 \mathrm{~m} \mathrm{~s}^{-2}$, average trunk surface slope of $4.8^{\circ}$, average tributary icefall slope of $23^{\circ}$ and a parabolic shape factor of 0.646 (trunk) or 0.806 (tributary). The resulting basal shear stress ranges of 95-143 kPa (trunk) and $55-139 \mathrm{kPa}$ (tributary) agree with the expected ranges 50-150 kPa for their respective glacier size, elevation range and geometry (Cuffey and Paterson, 2010; Linsbauer and others, 2012).

ii. We inversely derived a maximum expected trunk centreline depth $\left(C^{*}\right)$ by assuming flow to be by internal deformation (Cuffey and Paterson, 2010: Eqn (8.35)). With a creep parameter $\mathrm{A}$ of $2.4 \times 10^{-24} \mathrm{~s}^{-1} \mathrm{~Pa}^{-3}$, exponent $n=3$, and measured trunk centreline velocity equal to velocities in stake transects $\mathrm{T} 1$ and $\mathrm{T} 2\left(26.5 \mathrm{~m} \mathrm{a}^{-1}\right.$ when averaged over all stakes and all years; $30.6 \mathrm{~m} \mathrm{a}^{-1}$ maximum centreline velocity) and to speckle trackingderived centreline velocity in the two trunk fluxgates (20-42 $\mathrm{m} \mathrm{a}^{-1}$ : Figs 3b, c). C* has to be set to 284-294 m to match the stake velocity range and to $265-319 \mathrm{~m}$ to match the speckle-tracking velocity range. Reversely,

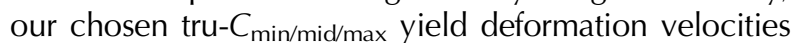
of $6.5,15.9$ and $33.0 \mathrm{~m} \mathrm{a}^{-1}$, respectively, where basal slip accounts for $80 \%$ of the surface velocity for tru- $C_{\text {min, }}$ $50 \%$ for tru- $C_{\text {mid, }}$ while all movement is by internal deformation for tru- $C_{\max }$. Given our measured surface velocities and inferred basal slip to surface velocity ratios for the trunk centreline depths, we infer that tru- $C_{\operatorname{mid} / \max }$ are probably more realistic depths than tru- $C_{\min }$ (c.f. Raymond, 1971; Cuffey and Paterson, 2010). Our tri$C_{\mathrm{min} / \mathrm{mid} / \mathrm{max}}$ yield deformation velocities of $0.1,1.2$ and $5.1 \mathrm{~m} \mathrm{a}^{-1}$, respectively, where basal slip accounts for $>95 \%$ of the tributary centreline surface velocity of 160 $\mathrm{m} \mathrm{a}^{-1}$ in all cases. This is characteristic of icefalls.

iii. Present-day ice thicknesses modelled by Clarke and others (2015) at a $200 \mathrm{~m}$ grid resolution, yield 34-58 $\mathrm{m}$ nearest to our tributary fluxgate and $167 \mathrm{~m}$ in the deepest part of the tributary. Due to imprecise glacier outlines, the dataset omits ice in most of our trunk valley, the confluence zone and the entire downstream tongue, thus preventing direct comparison with our trunk fluxgates. Yet, ice thickness of $335 \mathrm{~m}$ in the deepest grid of the trunk, $4 \mathrm{~km}$ upstream of our fluxgates (Fig. 1a: TS2), suggests our trunk fluxgate-averaged depths of $145-216 \mathrm{~m}$ for the $\operatorname{tru}-C_{\mathrm{min} / \mathrm{mid} / \mathrm{max}}$ scenarios appear reasonable. 
Table 2. Tributary/Trunk flux ratios for nine possible combinations of trunk and tributary centre midpoint thickness $(C)$ scenarios

\begin{tabular}{lccc} 
& \multicolumn{3}{c}{ Tributary/Trunk flux ratio } \\
\cline { 2 - 4 } & $\operatorname{tru}-C_{\min }=200$ & $\operatorname{tru}-C_{\text {mid }}=250$ & $\operatorname{tru}-C_{\max }=300$ \\
\hline $\operatorname{tri}-C_{\min }=20$ & 0.47 & $\mathbf{0 . 3 9}$ & $\mathbf{0 . 3 3}$ \\
$\operatorname{tri}-C_{\operatorname{mid}}=35$ & 0.74 & $\mathbf{0 . 6 0}$ & $\mathbf{0 . 5 1}$ \\
$\operatorname{tri}-C_{\max }=50$ & 1.01 & 0.82 & 0.70 \\
\hline
\end{tabular}

Ratios $<1$ indicate fluxes in the trunk are higher than in the tributary. The four most likely ratios are given in bold.

iv. Using speckle-tracking, we calculated ice flux in two fluxgates 600 and $800 \mathrm{~m}$ downstream of the tributarytrunk junction (Fig. 1d: BJ) to verify flux continuity. Using depth and flux calculations (Section 3.1.3), centreline velocities of $65-78 \mathrm{~m} \mathrm{a}^{-1}$, basal shear stress of $100-150 \mathrm{kPa}$, surface slope of $10.0^{\circ}-14.6^{\circ}$, shape factors of $0.445-0.545$, the estimated centreline glacier depth below the junction is $125-180 \mathrm{~m}$ (see also Section 5.2). This yields a below-junction flux in the range $1.9 \pm 0.3$ to $2.6 \pm 0.4 \times 10^{6} \mathrm{~m}^{3}$, which is equivalent to, or about one third lower than, the most likely sum of tributary and trunk fluxes (Tables 1 and 2 bold: $2.2 \pm 0.7$ to $3.3 \pm 0.82 \times 10^{6} \mathrm{~m}^{3}$ ). The flux difference conforms to the expected lower value below than above the junction, as mass loss by ablation is high in icefalls.

\subsection{Structural glaciology}

\subsubsection{Field-based measurements and analysis}

Field-based structural measurements of crevasses and crevasse traces were done between 20 July and 3 August 2010. Along each velocity transect (T1; T2; T3), we sampled the first crevasse encountered upstream and downstream of each stake, resulting in $\sim 50 \mathrm{~m}$ across-flow spacing and $\sim 100 \mathrm{~m}$ along-flow spacing. Two additional along-flow transects on either side of the glacier connecting the furthest proximal and furthest distal stakes of the cross transects $(\mathrm{T} 1$ and T2) were measured with $\sim 100 \mathrm{~m}$ along-flow spacing. In areas of low crevasse density $(<1$ per $50 \mathrm{~m}$ ) each crevasse encountered was measured. Additional crevasses were measured up to $100 \mathrm{~m}$ downstream of the lower transect in the proximal junction with the tributary, but crevasse size and density increased further downglacier, prevented safe traversing. Crevasse location was measured using an eTrex handheld GPS $( \pm 4 \mathrm{~m})$. Strike and dip were measured with clinometer compasses (Suunto and Silva: $2^{\circ}$ precision), using the left-hand rule (Fig. 2c). Crevasse width and depth were measured with a tape measure ( $\mathrm{mm}$ precision). Crevasse length, type and density per $25 \mathrm{~m}$, were also recorded in the field, but were superseded by glacier-wide measurements from a SPOT scene. For crevasse traces, the location, strike and density were recorded. Additional structural features were recorded as encountered, with at least location and description or photographs. In total, 93 crevasses and 36 crevasse traces were measured, and nine sediment squeezes, six moulins and one supraglacial meltwater fountain were recorded.
Crevasses and crevasse traces were plotted in ArcGIS 9.3.1, and strike and dip were visualised using rose diagrams and planes-to-poles Schmidt diagrams, generated using OpenStereo 0.1 Beta software (http://www.igc.usp.br/index. php?id=openstereo). Density statistics were conducted using Natural Neighbour contouring in OpenStereo for a Gaussian point distribution in order to compare strike and dip variability on proximal and distal sides of the glacier. Descriptive and inferential statistics (t-tests) were conducted to test for differences in strike, dip, width and depth between proximal and distal sides.

\subsubsection{Remote-sensing derived structural measure- ments and analysis}

A panchromatic SPOT 5 scene (529-244: 30 August 2009) with $2.5 \mathrm{~m}$ resolution and a $26.62^{\circ}$ incidence angle was used to trace large crevasses and ogives in the mid-elevation region of the trunk glacier, upstream of the tributary junction. The SPOT scene was georeferenced to Landsat 7 scene L72045024_02420000817, and projected in WGS1984 in ArcMap 9.3.1. Using the glacier shapefiles and $20 \mathrm{~m} \times 20 \mathrm{~m}$ resampled DEM from Jiskoot and others (2009), icefall regions were delineated for slopes steeper than $18^{\circ}$. Icefall margins were manually improved by digitizing around nunatak rock outcrops using SPOT and Landsat scenes and Google Earth v6.0.1.2032. Crevasses and band ogives were manually digitised along the extent of the three confluent flow units comprising the main trunk, using SPOT Band 3 false colour. Crevasses were verified using field measurements and field photography, and historic aerial photographs (4 August 1997; frame numbers 72-74, 115-116, 149-151, 233-234; Global Remote Sensing, Edmonton, Alberta). Band ogives were manually digitised, from the first occurrence below their icefalls until they became no longer visible, in order to approximate multi-decadal ice flow speed and regions of compression and extension. No ogives could be traced along the margin of the proximal flow unit due to supraglacial debris extending as far as 200 $\mathrm{m}$ from the valley wall. Crevasse density was calculated by converting the centre of crevasse polylines to points, and conducting a point density analysis. An ArcMap point density tool with a $200 \mathrm{~m}$ radius circular neighbourhood provided the most detailed gradient from areas of high to low crevasse density. Digitised crevasse length and density $t$ test statistics were calculated to compare the proximal and distal sides of the trunk glacier.

\subsubsection{Elevation data}

Elevations were derived from a $20 \mathrm{~m} \times 20 \mathrm{~m}$ resampled DEM (Jiskoot and others, 2009), which is equivalent to the 1: 250000 CDEM, except at the highest elevations outside our area of interest. These data were corroborated with point-elevation data derived from our field surveys. Elevations along two flow transects, on the distal and proximal sides from the upper icefalls to below the tributary-trunk junction, were acquired by creating a $10 \mathrm{~m}$ buffer around each transect and extracting the DEM raster data using the Extract by Mask tool: see Jiskoot and others (2009) for its use on snowlines. We use elevation together with slope to analyse crevasse density patterns, and in combination with estimated ice thickness as a proxy for normalised bedrock step and hanging valley heights. 


\section{RESULTS}

\subsection{Ice flow}

\subsubsection{Basin-wide velocity from speckle-tracking}

Figure 3a shows the basin-wide smoothed and resampled velocity of Shackleton Glacier derived from speckle-tracking. In the accumulation basins (icefield plateau) of flow units 1-3 velocities increase from $10-25$ to $\sim 150 \mathrm{~m} \mathrm{a}^{-1}$ in the icefall zones $2 \mathrm{~km}$ downglacier of the heads of these flow units. Velocities stabilise to $\sim 60 \mathrm{~m} \mathrm{a}^{-1}$ in the main trunk below the flow unit 1 icefall, until an oval chaotic crevasse feature is reached where ice flow has mainly vertical components and is too chaotic to be resolved with speckle tracking (Fig. 3: grey zone at TS1 stake). In the field, this feature manifests as an $8 \mathrm{~m}$ deep depression with overlapping crevasses and collapse structures. Flow speed in the immediate surroundings of this feature can be resolved, but uniform flow direction not. Further downstream, near the tributary-trunk confluence $(\sim 2.5 \mathrm{~km}$ from the terminus) velocities diminish from 60 to $15 \mathrm{~m} \mathrm{a}^{-1}$, suggesting compressive flow and some outflow restriction by the tributary, however, at the junction velocity rapidly increases to $50-75 \mathrm{~m} \mathrm{a}^{-1}$ into the lower icefall. The distance over which the upstream slowdown occurs, $\sim 700-800 \mathrm{~m}$, corresponds to 3-4 times the estimated ice thickness range (200-300 m) and is in agreement with the longitudinal coupling scale (Cuffey and Paterson, 2010). In the lowermost narrow terminus the ice flow slows to $<15 \mathrm{~m} \mathrm{a}^{-1}$. In the main tributary (flow unit 4) velocities increase from $10-50 \mathrm{~m} \mathrm{a}^{-1}$ in the accumulation region to $50-175 \mathrm{~m} \mathrm{a}^{-1}$ along the lower $2 \mathrm{~km}$ and into its icefall. It is the first time that complex glacier-wide flow is measured at this resolution in the Canadian Rockies, expanding upon the interferometric ice flow extraction of the Columbia Icefield (e.g. Mattar and others, 1998).

\subsubsection{Velocity upstream of the tributary-trunk junction from stake measurements}

Surface stake transect velocities over 4 years (2006-10) show the highest field-measured flow speeds of $30-35 \mathrm{~m} \mathrm{a}^{-1}$ in the upper section of longitudinal transect T3 (Figs 4a, b). The upper $200 \mathrm{~m}$ of T3 consistently flows $2-4 \mathrm{~m} \mathrm{a}^{-1}$ faster than the middle $300 \mathrm{~m}$, while the lower $200 \mathrm{~m}$ marginally speeds up as the glacier approaches the tributary-trunk junction. The transverse flow transects $\mathrm{T} 1$ and $\mathrm{T} 2$ (Fig. 4c) are slightly convex, increasing from $19-21 \mathrm{~m} \mathrm{a}^{-1}$ on the distal side to $29-31 \mathrm{~m} \mathrm{a}^{-1}$ around the medial moraine, to $26-28$ $\mathrm{m} \mathrm{a}^{-1}$ on the proximal side. The higher flow speed on the proximal side may be due to the larger distance of the proximal unit's stakes to the glacier margin, which could not be drilled closer than $200 \mathrm{~m}$ to the proximal valley wall due to rock fall, surface debris and un-navigable crevasses. Figure $4 \mathrm{~d}$ reveals the difference in flow speed between the upper and lower transverse transects, averaged over the 4 years. At every point on the proximal side the lower transect (T1) is faster than the upper (T2), while, conversely, most stakes on the distal side slow down in a downglacier direction. Moreover, almost all stakes on the proximal side move obliquely towards the medial moraine, whereas stakes on the distal side move in a direction parallel to the valley walls and the distal lateral moraine. This flow pattern suggests that the tributary pushes the proximal flow unit towards the centre flowline, but instead of restricting the flux it funnels it towards the icefall. This pattern was also seen in the speckle-tracking results (Fig. 3).

The elevation difference between the upper and lower stakes of T3 is $\sim 67 \mathrm{~m}$ with a downglacier slope decreasing from $4.7^{\circ}$ to $3.2^{\circ}$. Transverse elevation profiles are slightly parabolic, with a maximum height difference between margin and centre of $\sim 8 \mathrm{~m}$ (T1) and $\sim 5 \mathrm{~m}$ (T2), and a lowest elevation along the margin of the distal unit. The medial moraine is $\sim 5 \mathrm{~m}$ higher than the surrounding ice (and the adjacent stakes). Due to movement and surface ablation, stakes are at a 15-20 m lower elevation in 2010 than in 2006, which would lead to an 0.5-1.5 $\mathrm{m} \mathrm{a}^{-2}$ deceleration if all movement were by internal deformation. This rate is $25-50 \%$ higher than the observed deceleration rate (Figs $4 \mathrm{~b}, \mathrm{c}$ ), and may be compensated by the downstream speed up towards the icefall. Moreover, year-to-year flow variability related to changes in mass balance and subglacial hydrology are superimposed onto these trends. The relatively high flow rate in 2006/07 (Figs 4b-d) may have been in response to the highest snow accumulation since records started $(170 \%$ of the average accumulation between 1980 and 2015). The snowpack disappeared 3-4 weeks later than in other years at the nearest automatic snow pillow (Molson Creek, 2A21P, British Columbia River Forecast Centre, http://bcrfc.env.gov.bc.ca/data/).

\subsubsection{Velocity comparison: speckle-tracking versus ground measurements}

Figures 3b-d show that the annual velocities of the surveyed stakes compares fairly well with the velocity pattern derived from speckle tracking, with differences in flow speed $<10 \mathrm{~m} \mathrm{a}^{-1}$. In Figure $3 \mathrm{~d}$ we show two longitudinal transect lines with adjacent line centre-points, both representing the extended longitudinal transect derived from speckle tracking (T3-T3'). The higher divergence between the lines near the oval chaotic crevasse feature and the icefalls shows that velocities derived from speckle-tracking averaging are highly dependent on their exact location in zones with large velocity gradients. To illustrate this more clearly, the field-derived velocities in the two upglacier stakes (yellow squares with GPS-derived velocities of $\sim 65$ and $\sim 50 \mathrm{~m} \mathrm{a}^{-1}$ ) compare within $3 \mathrm{~m} \mathrm{a}^{-1}$ with the velocities derived from the speckle tracking, but stake TS1 with one and TS2 with the other flowline (Figs 3a, d). Therefore, adjacent speckle-tracking transects with a lateral spacing of only 25 $\mathrm{m}$ can differ significantly when cross-glacier velocity gradients are large, resulting in velocity differences in the order of $30 \mathrm{~m} \mathrm{a}^{-1}$. This sensitivity to exact location of the speckle-tracking velocity is also visible in the centre of T1 (Fig. 3b). Here, it helps to explain the systematically higher stake-derived velocities (Fig. 3c), though differences are within the $\pm 10 \mathrm{~m} \mathrm{a}^{-1}$ uncertainty estimate of the speckletracking method (Section 3.1.2). The similarity in relatively flat cross-transect velocity profiles, and the absence of a systematic velocity difference between the speckle-tracking derived annual velocities (based on a 3-month interval during winter) and ground measurements (near-annual measurement interval), suggest that the seasonal variation is minimal, and some basal sliding likely occurs throughout the year. Overall, our remote-sensing to ground measurement comparison is in agreement with Mattar and others (1998) on the nearby Saskatchewan Glacier, with the main advantage of our speckle tracking results that 

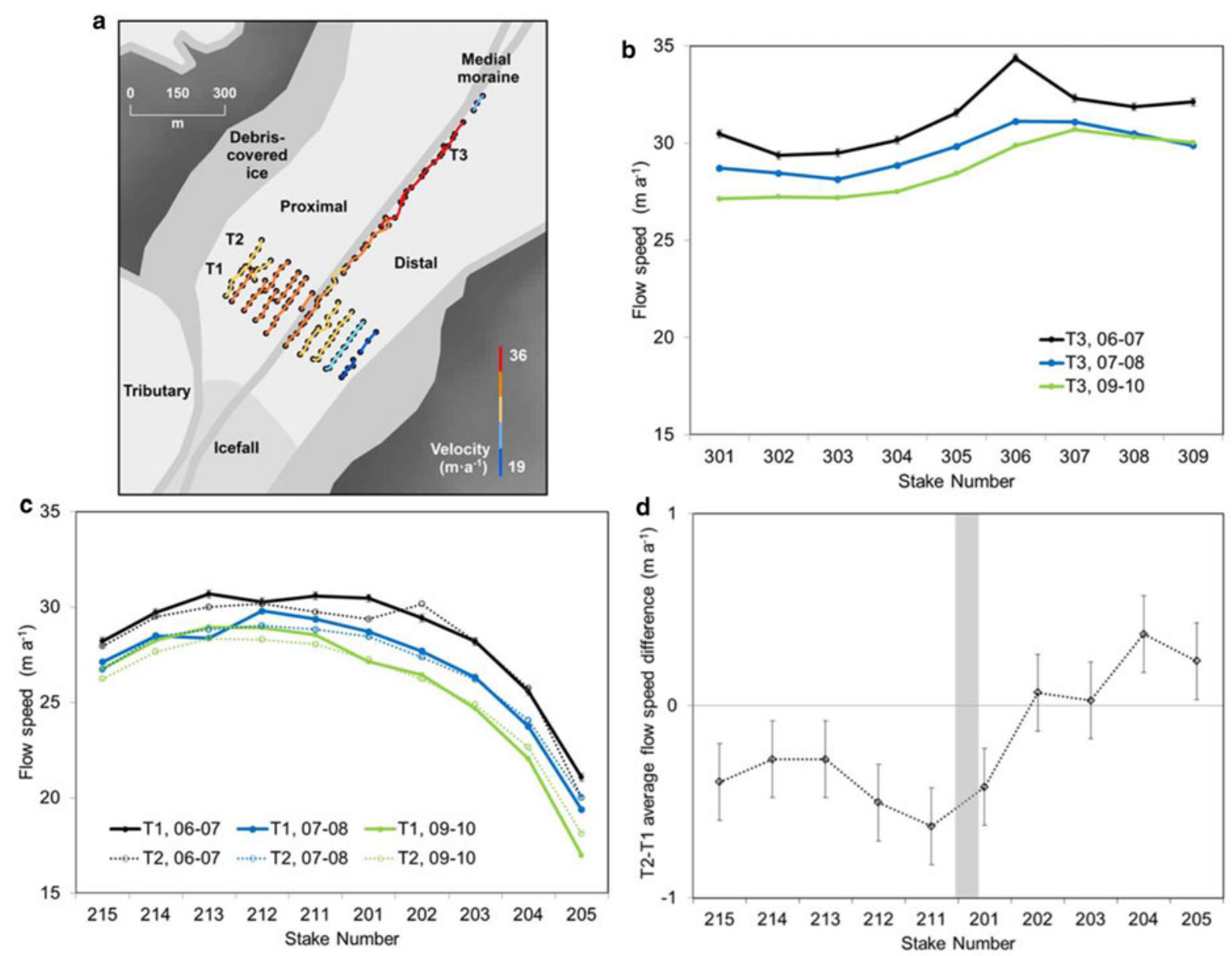

Fig. 4. (a) Annual stake positions (black dots) and velocities (colour gradient lines) from field measurements between 2006 and 2010 . The two dots on the crest of the medial moraine is a marked rock surveyed in 2008 and 2009 only. Three stakes had fallen into crevasses and were redrilled in the subsequent year. (b-c) Flow speed along the longitudinal transect (T3) and transverse transects (T1-T2) over three annual periods. In T3 stakes were numbered from downglacier (301) to upglacier (309); in T1 and T2 from the medial moraine to the distal margin (201-205) and the proximal margin (211-215). Stake 205 was buried by an avalanche in 2007, 2008 and 2009: only its average speed between 2006 and 2010 is shown. (d) Average annual flow speed difference between the upper (T2) and lower (T1) transverse transect, indicating extensional flow in the proximal unit and compressional flow in four stakes of the distal flow. Error bars reflect the average measurement error.

we are able to resolve ice motion on a variety of differing flow orientations and with a more simplistic image processing scheme than is required of interferometric processing.

\subsubsection{Ice flux of trunk relative to tributary}

Speckle-tracking-derived ice flow velocities across two trunk fluxgates and one tributary fluxgate range from $24-35 \mathrm{~m} \mathrm{a}^{-1}$ in $\mathrm{T} 1,12-25 \mathrm{~m} \mathrm{a}^{-1}$ in $\mathrm{T} 2$ and $105-160 \mathrm{~m} \mathrm{a}^{-1}$ in the tributary (Fig. 3). Table 1 summarises the calculated ice fluxes for the average of the two adjacent trunk fluxgates (T1 and T2) and for the tributary fluxgate, each according to the minimum, median and maximum ice thickness scenarios (Section 3.1.3 and Fig. $1 \mathrm{~d}$ ).

The tributary and trunk flux results give nine possible $Q_{\text {trib }} / Q_{\text {trunk }}$ flux ratios (Table 2), ranging from 0.33 to 1.01 , where ratios $<1$ indicate a trunk flux exceeding the tributary flux. Ratios near 1 are highly implausible, given the combined area of the three basins feeding the trunk is about twice as large as that of the single basin feeding the tributary, as well as the relative valley shapes. Therefore, the most likely flux scenarios are for a tributary fluxgate centreline thickness of 20-35 m, and, as justified in Section 3.1.4, a trunk maximum depth range of 250-300 m (Table 2: bold). The envelope of these four values (0.3-0.6) will be considered in our discussion of the bedrock step formation. Taking flux uncertainties (Table 1) into account when calculating the flux ratios does not significantly affect the bounds of this envelope.

\subsection{Structural glaciology}

\subsubsection{SPOT scene measurements: crevasses}

Figure 5 and inset display a variety of crevasse types as simple traced crevasse lines. The spatial distribution and structural configuration of many of Shackleton's crevasses are similar to other valley glaciers, and reflect the wellknown explanation by Nye (1952) that crevasses open in the direction of maximum tension. In a valley glacier of constant width with steady flow dominated by internal deformation valley wall drag causes marginal crevasses with upglacier oriented angles of $45^{\circ}$ or more; compressing flow results in splaying of marginal crevasses, and strong compression results in longitudinal crevasses, thrust faults, and radial longitudinal crevasses where ice can expand laterally; extending flow results in transverse crevasses extending arcuate upglacier across the entire glacier width. Crevasse 


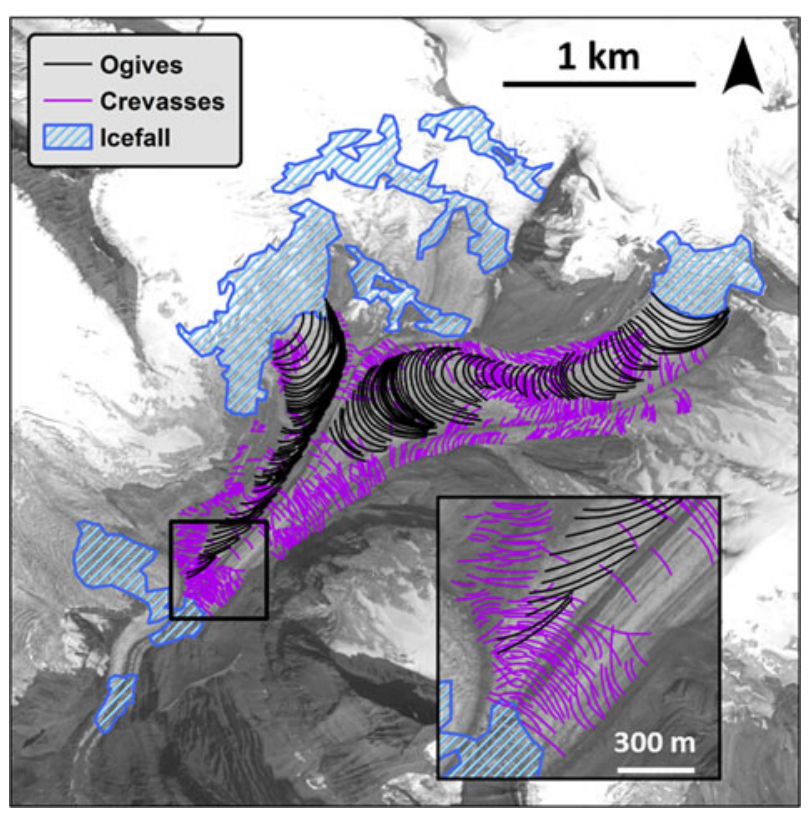

Fig. 5. Icefalls (slopes $>18^{\circ}$ ), ogives, and major crevasses digitized from the 2.5 m resolution SPOT 5 scene (529-244: 30 August 2009). Inset shows detail of crevasse patterns near the tributary-trunk junction that were used for local area crevasse length calculations (see Table 3).

fields are mainly in response to the average bulk stress field, and when travelling through different stress regimes they can become rotated, or close to form crevasse traces. In addition, local discontinuities can also result in specific stress patterns and resulting local crevasses (Meier and others, 1974; Glasser and others, 1998; Hambrey and Lawson, 2000; Colgan and others, 2016). On Shackleton Glacier, expected crevasse patterns included: (i) arcuate upward and transverse crevasses in longitudinal extensional zones that correspond to increases in flow speed upstream of icefalls and in the narrowing trunk valley; (ii) longitudinal crevasses and active splaying crevasses indicating lateral extension at the base of the upper icefalls; (iii) marginal short splaying crevasses with angles of $45^{\circ}$ in uniform velocity regions of the main trunk; (iv) upward splaying longer crevasses where the trunk enters the narrowing valley and marginal shear becomes high and compressive; and (v) some chevron and en echelon crevasses in rotating marginal bends in the upper and middle regions of the main trunk.

Crevasses digitised from the SPOT scene are used here for comparison of crevasse occurrence and density between the proximal and distal sides of the trunk glacier, relative to the tributary (See Fig. 2b). Table 3 provides digitized crevasse lengths on the proximal and distal sides, and in the local area upglacier from the tributary-trunk junction (Fig. 5: inset). It is evident that crevasses near the tributary-trunk junction are consistently longer on the distal side, and shorter but more numerous on the proximal side.

The crevasse point density analysis generated a point density range from 0 to 355 crevasses per square $\mathrm{km}$ (Fig. 6a). From this we extracted two flowlines (Fig. 6b) combining elevation, slope and crevasse densities. The average elevation of the proximal unit is $5-10 \mathrm{~m}$ higher than the distal unit and the minimum glacier surface slope in the proximal unit is $1^{\circ}-2^{\circ}$ over a distance of $100 \mathrm{~m}$, relative to a minimum of $3^{\circ}-4^{\circ}$ on the distal side (Fig. 6b). These results
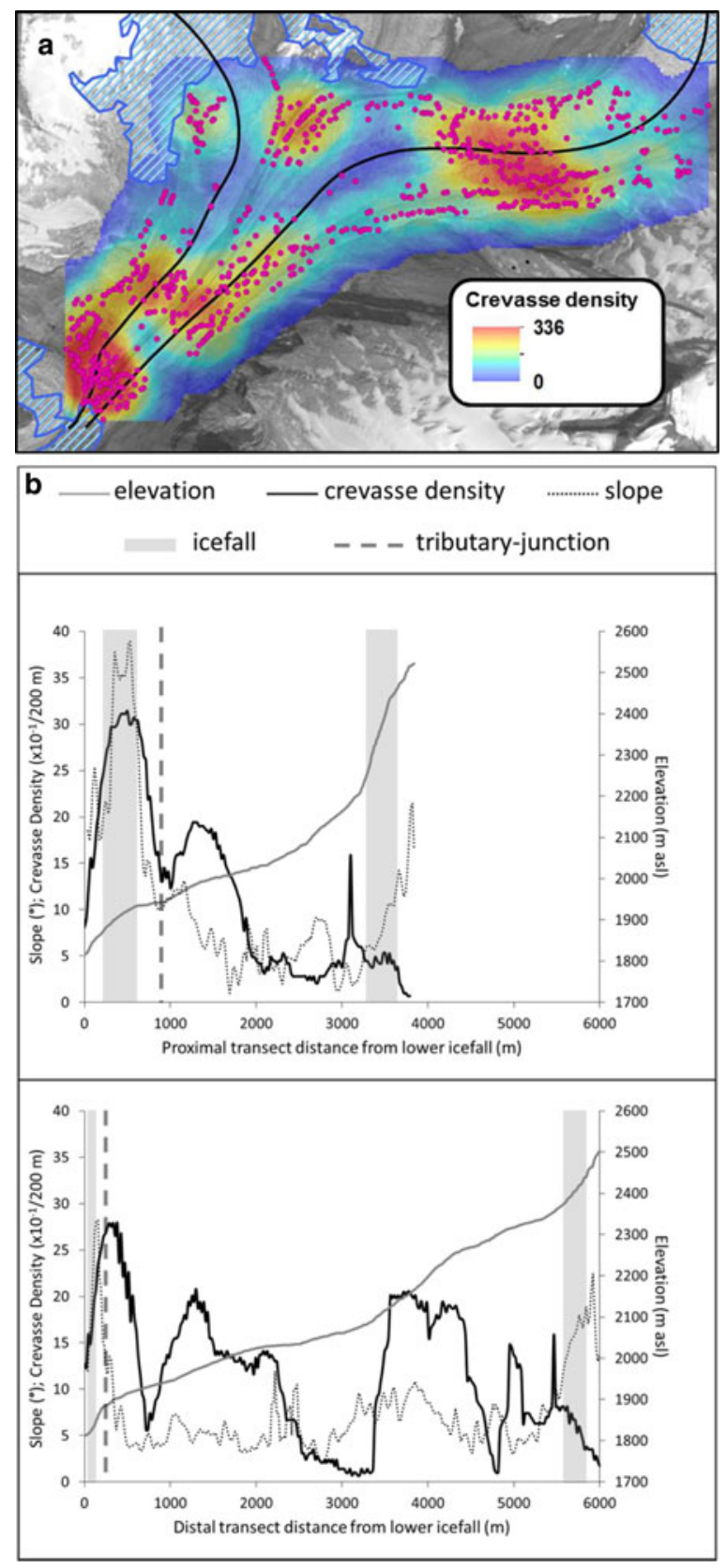

Fig. 6. (a) Crevasse point density map using digitized crevasse polyline centres (circles) and a $200 \mathrm{~m}$ search radius, displayed as 0-336 crevasses per $\mathrm{km}^{2}$. (b) Elevation, slope and crevasse density transects (black lines in a) in the proximal and distal units above and below the tributary junction.

suggest a slight ice thickening upstream of the tributary. Along each flowline the crevasse density primarily reflects the slope gradient. In the distal flow unit, crevasse density increases gradually from low to high over $2 \mathrm{~km}$ from the icefall base to the oval chaotic crevasse feature, downstream of which a low density compressive region develops upglacier of the trunk confluence. In the proximal unit, crevasse density is low up to $\sim 1.5 \mathrm{~km}$ from the icefall base, transitioning into medium density over $400 \mathrm{~m}$, and decreasing to medium to low density in the compressive zone $\sim 400$ $800 \mathrm{~m}$ upglacier of the tributary-trunk junction. In both the proximal and distal sides, the highest crevasse densities $\left(>300 \mathrm{crev} . \mathrm{km}^{-2}\right.$ ) occur in the extensional zone within $500 \mathrm{~m}$ upglacier of the tributary-trunk junction to the lower icefall. Crevasses increase in abundance $\sim 300 \mathrm{~m}$ upstream 
Table 3. Crevasse length $(\mathrm{m})$ on proximal and distal sides of the glacier trunk, relative to the tributary

\begin{tabular}{|c|c|c|c|c|c|}
\hline & \multicolumn{2}{|l|}{ Proximal } & \multicolumn{2}{|l|}{ Distal } & \multirow{2}{*}{$\begin{array}{l}\text { Overall } \\
\mathrm{m}\end{array}$} \\
\hline & $\begin{array}{l}\text { Local } \\
\mathrm{m}\end{array}$ & $\begin{array}{l}\text { All } \\
\mathrm{m}\end{array}$ & $\begin{array}{l}\text { Local } \\
\mathrm{m}\end{array}$ & $\begin{array}{l}\text { All } \\
\mathrm{m}\end{array}$ & \\
\hline $\mathrm{N}$ & 143 & 193 & 66 & 461 & 692 \\
\hline Mean \pm SD & $102 \pm 58$ & $106 \pm 61$ & $133 \pm 58$ & $147 \pm 74$ & $130 \pm 73$ \\
\hline Min & 17 & 17 & 53 & 16 & 16 \\
\hline Max & 321 & 321 & 344 & 401 & 401 \\
\hline
\end{tabular}

Local is the zone is directly upglacier of the tributary-trunk junction (Fig. 5: inset).

a moderate increase in slope, and 500-600 m upstream of an icefall zone. Tensile stress and longitudinal coupling is usually averaged over a length scale of three times the ice thickness for temperature valley glaciers with a high proportion of sliding (Cuffey and Paterson, 2010). For Shackleton Glacier the coupling would be averaged over 600-900 m upstream of the trunk icefall.

One of the major differences in crevasse patterns between the proximal and distal sides is the distribution and density of transverse crevasses 2500-500 m upstream of the lower icefall (Fig. 6). On the distal side, transverse crevasses become relatively abundant at $2300 \mathrm{~m}$ upstream of the lower icefall, followed by a $1.2 \mathrm{~km}$ long region of medium crevasse density, before terminating abruptly in the compressive zone that extends from 700 to $800 \mathrm{~m}$ upglacier from the lower icefall. On the proximal side, a low crevasse zone occurs from 3000 to $1800 \mathrm{~m}$, and the medium crevasse zone is limited to 1800-1000 upstream of the icefall, and contains fewer and shorter crevasses. The compressive zone is from 1000 to $800 \mathrm{~m}$, but has a higher crevasse

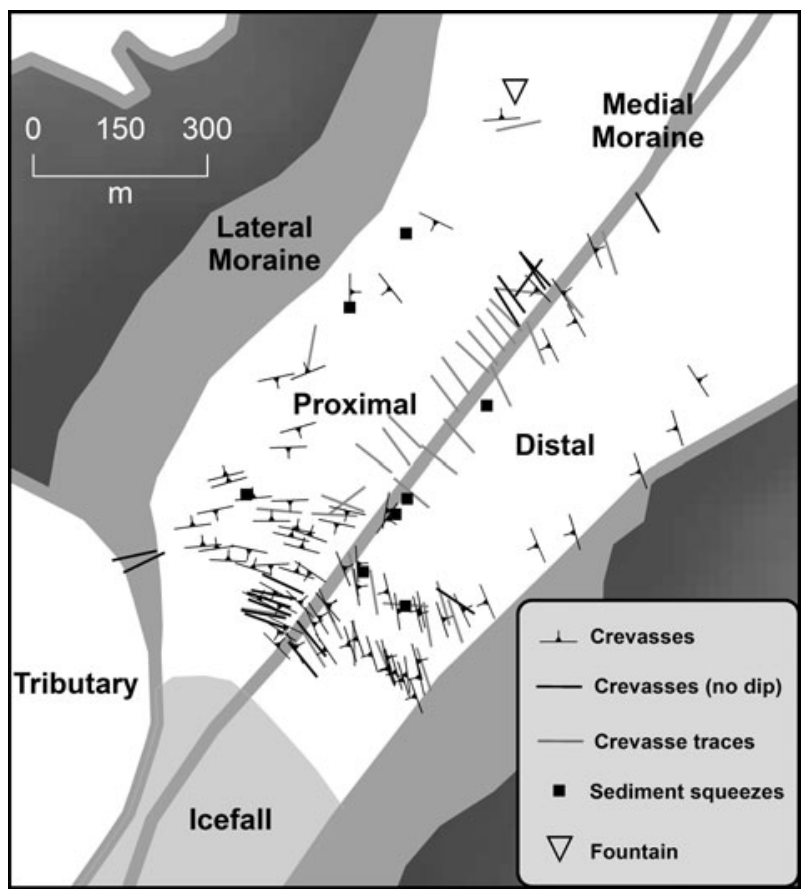

Fig. 7. Map of structural features measured in the field, including 93 crevasses, 36 crevasse traces, nine sediment squeezes and one fountain. Strike-dip symbols for crevasses are oriented according to the left-hand rule. Glacier flow is from top right to bottom left. density $(13 / 200 \mathrm{~m})$ than on the distal side (5/200 m). Further differences occur along the margins: while some splaying crevasses are present on the proximal side, these are almost entirely lacking on the distal side. In the tributary trunk junction zone, long splaying marginal crevasses have formed on the distal side, mirroring those in the compressive zone on the proximal side, although slightly further downglacier.

The distal and proximal units in the main trunk show the same general pattern of tensional stress in the upper transects to compressive stress in their zone of confluence, and back to tensional in the zone 500-700 m upglacier of the icefall. Both the elevation difference, although minor, between the proximal and distal units and the longer and stronger compressive zone on the proximal side suggests that the tributary causes some minor outflow restriction. Overall, crevasses show lower extensional force on the proximal side in that they are shorter and narrower, and although mainly transverse, more variable in orientation.

\subsubsection{SPOT scene measurements: ogives}

All flow units feed the main trunk through substantial icefalls (Fig. 5: blue hatching), generating band ogives that are discernible from the ground and from SPOT imagery. Below the upper icefall of flow unit 1 , a total of 68 ogives were identified on the SPOT scene (Fig. 5). These extend to $3.3 \mathrm{~km}$ downstream of their icefall, after which they become indiscernible. Based on ogive spacing, the average flow rate in this part of Shackleton's trunk is $51 \mathrm{~m} \mathrm{a}^{-1}$, with a range $\sim 20-61 \mathrm{~m} \mathrm{a}^{-1}$. In the proximal flow unit, 48 ogives were traced along a distance of $2.2 \mathrm{~km}$ from the base its icefall to the tributary-trunk junction. Here, the average flow speed is $50 \mathrm{~m} \mathrm{a}^{-1}$, with a range $\sim 24-55 \mathrm{~m} \mathrm{a}^{-1}$ between compressive and extensional regions in upper and lower elevations, respectively. These flow speeds correspond well with velocities measured along the same transects using speckle-tracking and from the upper two flow stakes (Fig. 3d).

While ogives in the distal flow unit remain oriented perpendicular to ice flow along their trajectory, indicating an absence of lateral compression or extension, ogives in the proximal unit are only perpendicular to iceflow in the first $700 \mathrm{~m}$ below the base of their icefall. Further downglacier they orient obliquely to iceflow in the main trunk over the remaining $1.5 \mathrm{~km}$, and are almost parallel to the medial moraine in the lower $300-400 \mathrm{~m}$ of the trunk (Fig. 5a: inset). We interpret this as strong compression between the base of the icefall and the upper part of the medial moraine, followed by a block-like flow parallel to the medial moraine in the proximal unit, until they reach an extensional flow zone where the first transverse crevasse crosses the medial moraine.

\subsubsection{Field measurements of structures}

The configuration of field-measured crevasse patterns suggests that a strong compressive regime occurs only in the proximal flow unit. Crevasses are abundant in the region of the cross transects and below, but sporadic in the middle to upper reaches of the four longitudinal transects measured in the field (Fig. 7). The majority of crevasses upstream of $\mathrm{T} 2$ are splaying marginal crevasses, indicating moderate marginal compression from the narrowing of the trunk valley. Crevasse traces are prevalent upglacier from the cross transects T1 and T2, especially in the proximal flow unit. 
Sediment squeezes generally coincide with these crevasse traces, as well as with thrust faults mapped in the upstream region of the proximal flow unit (upstream of the inset box in Fig. 5). One of these thrust faults with a higher upstream rim (Fig. 2e) occurred near a $30 \mathrm{~cm}$-high ephemeral fountain (Fig. 7). The occurrence of these thrust faults is coincident with en echelon crevasses near the medial moraine. Together, these structures indicate rotational strain near the medial moraine, and significant compressive stress in the rest of the proximal unit, even though, in non-surge-type glaciers, the active part of the thrust fault is likely not deeper than a few metres (c.f. Glasser and others, 1998; Moore and others, 2010). Downstream of T2 the crevasses are mostly transverse or arcuate, which we interpret to be responses to extensional stresses due to longitudinal coupling with the ice speed increasing toward the downstream icefall. In the proximal unit some longitudinal crevasses open perpendicular to the lateral compression from the tributary bulge (Figs 7, 2c, d).

Crevasses generally trend E-W on the proximal unit and NNW-SSE on the distal unit. The density statistic in the Schmidt diagrams (Fig. 8) shows a lower variability on the distal side (Gaussian point density $48.2 \%$; $n=40$ ), than on the proximal side (Gaussian point density $24.7 \%, n=36$ ). This discrepancy is mainly due to a more uniform direction of strike on the distal side, as the dip was uniformly steep on both sides $\left(81.7 \pm 6.1^{\circ}\right)$, though with a marginally higher probability $(4.1 \%)$ of dipping upglacier on the proximal side. More crevasses dip downglacier in the lower sections of the distal unit, while predominantly upglacier in that region on the proximal side. We interpret this as responses to longitudinal compression and lateral stretching caused by interaction with the tributary bulge. Statistical inference was also calculated for field-measured crevasse density, width, and depth, though none were significantly different between proximal and distal sides. Eight of the 93 crevasses were water-filled, of which seven were marginal crevasses on the distal side.

While we focus on crevasse patterns, as these are more instantaneous and short-lived transient reflections of local stress fields (Colgan and others, 2016) relating to the tributary-trunk confluence, two observed foliation patterns substantiate our crevasse results, as well as our depth scenarios. Longitudinal foliation planes, with a height difference of $20-40 \mathrm{~cm}$ between ridges and troughs due to differential ablation, occur along a distance of $\sim 2 \mathrm{~km}$ in the trunk parallel to the medial moraine (Figs 9a, b), reflecting strong transverse compression due to the narrowing of the trunk into its valley (Anderton, 1973; Glasser and others, 1998; King and others, 2015). Additionally, all foliation in the trunk showed complex folding with cross-cutting (Figs 9c, d), reflecting a complex cumulative strain history and evidence that all ice had travelled through the upstream ice falls (c.f. Hambrey and Lawson, 2000).

\section{DISCUSSION}

\subsection{What is the effect of Shackleton's tributary on the outflow of its trunk?}

Multiple lines of evidence in our study of Shackleton Glacier point to enhanced compressive stress hundreds of metres upglacier of the tributary entrance, but longitudinal and lateral increases in flow speed directly upstream of and at the junction, suggesting no net outflow restriction. The lateral movement of proximal stakes towards the medial moraine combined with between-transect increase in flow speed on the proximal side only, suggests an overall increase of flow speed towards a narrow outlet at the head of the icefall connecting the trunk to the tongue of the glacier (See also Fig. 2). This pattern is similar to that observed at Blue Glacier (Meier and others, 1974), where converging velocity vectors were measured where channel narrowing occurred, suggesting lateral compression and longitudinal extension towards an outlet. This particular tributary/trunk interaction configuration is most likely the result of the icefall below the tributary-trunk junction that is pulling the ice downglacier, and in doing so longitudinally pulling at the trunk ice that might otherwise be buttressing upstream of the tributary bulge. This 'funnelling' of ice explains the apparent lack of typical blocking signs, such as deceleration and accumulation/thickening of ice; spreading and acceleration of stakes towards the proximal margin (as blocked accumulating ice expands laterally: Nye, 1952), closing of transverse crevasses, and creation of a crevasse pattern with more variable crevasse orientations reflective of more complex stress fields. Furthermore, lateral expansion resulting from accumulation of blocked ice should yield splaying longitudinal crevasses (Hambrey and Lawson, 2000).

\subsection{What controls bedrock step size in glaciated longitudinal valley profiles?}

Using numerical modelling, MacGregor and others (2000) demonstrated that the size of a bedrock step increases with the ratio of the ice discharge in the tributary glacier $\left(Q_{\text {trib }}\right)$ to that in the trunk glacier $\left(Q_{\text {trunk }}\right)$ while, simultaneously, the height of the tributary's hanging valley decreases (Fig. 10). Here, we compare Shackleton Glacier's flux ratios and heights of its bedrock step and hanging valley to these modelled proportional outcomes. To our knowledge, this is the first time that an active glacier system and surrounding topography, rather than deglaciated valleys (Amundson and Iverson, 2006), are used to evaluate the model by MacGregor and others (2000).

With our velocity and depth scenarios we estimate that Shackleton's $Q_{\text {trib }} / Q_{\text {trunk }}$ is most likely in the range 0.3-0.6 (Table 3; Fig. 10: red zone). The morphology of Shackleton's basins suggests a similar flux ratio to today's would have existed during the Pleistocene when these basins were filled to the rim with Cordilleran Ice Sheet ice. Using surface elevation profiles along flow units 1, 2 and 4 we infer that: (1) the hanging valley height at flow unit 4 icefall is $450 \mathrm{~m}$ above the inferred bed of the trunk glacier; (2) the bedrock step height below the tributary-trunk confluence is the top 150-200 m of the entire step height (460 m). This top section is steepest, and after an initial surface elevation drop of $\sim 100 \mathrm{~m}$ the ice profile flattens abruptly to a subhorizontal zone with a length of 100-200 m. The lower section of the entire step is irregular and conforms to surrounding topographic relief. Assuming flux continuity and a basal shear stress range $100-150 \mathrm{kPa}$, ice thickness in the sub-horizontal zone is $50-100 \mathrm{~m}$, and therefore the bedrock step height is the sum of this surface elevation drop and ice thickness. Assuming a maximum localised longterm erosion rate of $1 \mathrm{~mm} \mathrm{a}^{-1}$ (Yanites and Ehlers, 2016), a $200 \mathrm{~m}$ high bedrock step will form in 200 kya or longer, hence over multiple glaciations. 

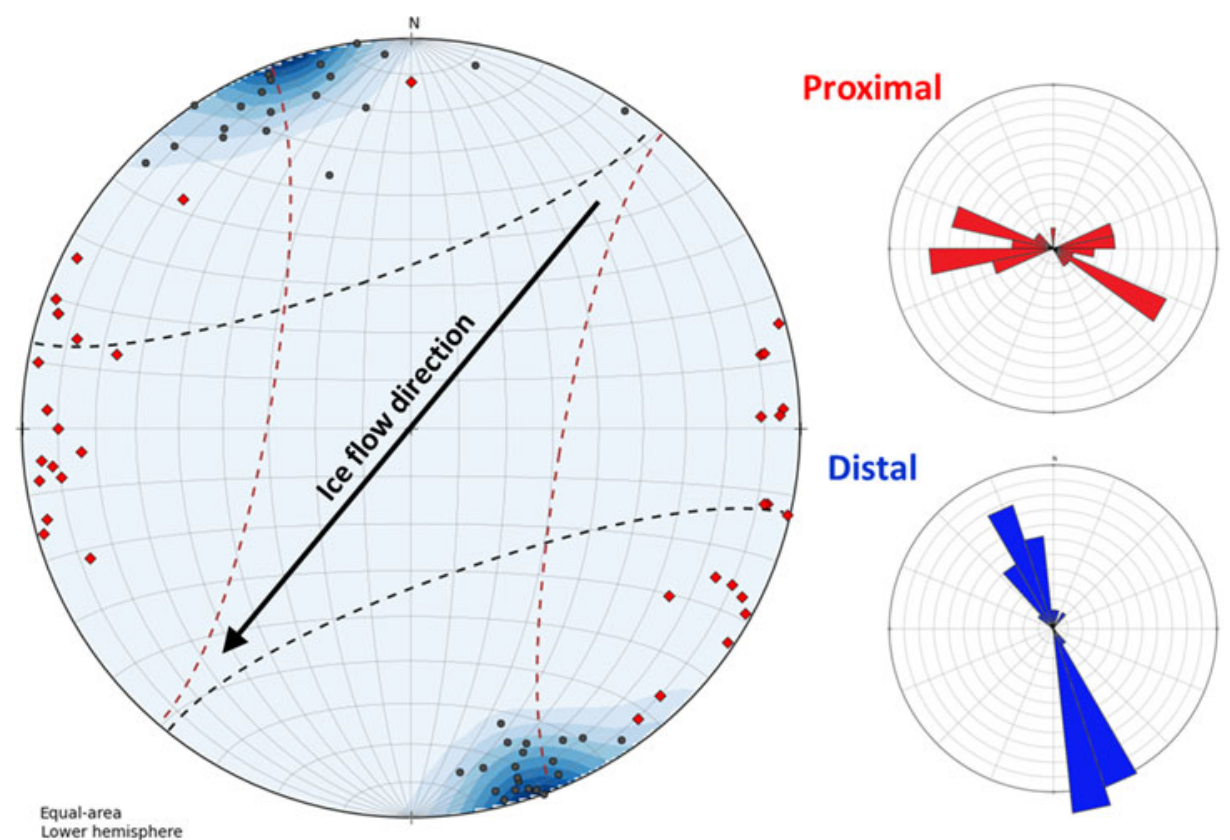

Fig. 8. Crevasse strike and dip distributions: (a) Strike and dip of proximal $(n=36)$ and distal $(n=40)$ flow units on a poles-to-planes equal area lower hemisphere Schmidt diagram. Contouring interval 5. (b) $360^{\circ}$ frequency class Rose diagram of distal crevasses. (c) $360^{\circ}$ frequency class Rose diagram of proximal crevasses.

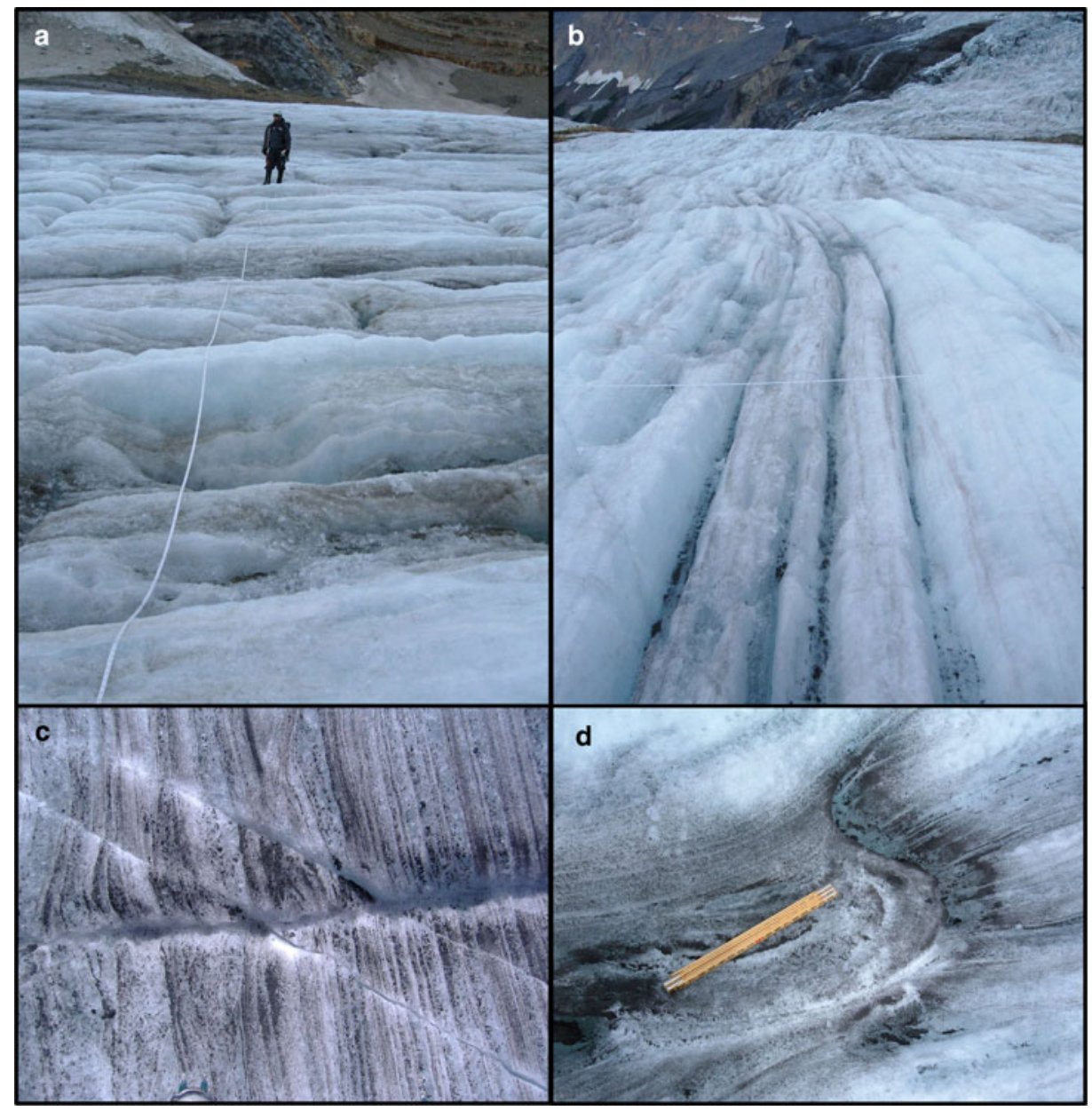

Fig. 9. (a) Longitudinal foliation in the distal flow unit. Ice flow from left to right. (b) Longitudinal foliation looking downstream the proximal flow unit. Across, white tape measure for scale. (c) Close-up of foliation that is bent, sheared and cross cut by crevasses. Ice flow from top to bottom. At bottom, boot tip with crampon spikes for scale. (d) Foliation boudinage and supraglacial debris. Ice flow from left to right. Measuring stick is $43 \mathrm{~cm}$ long. 


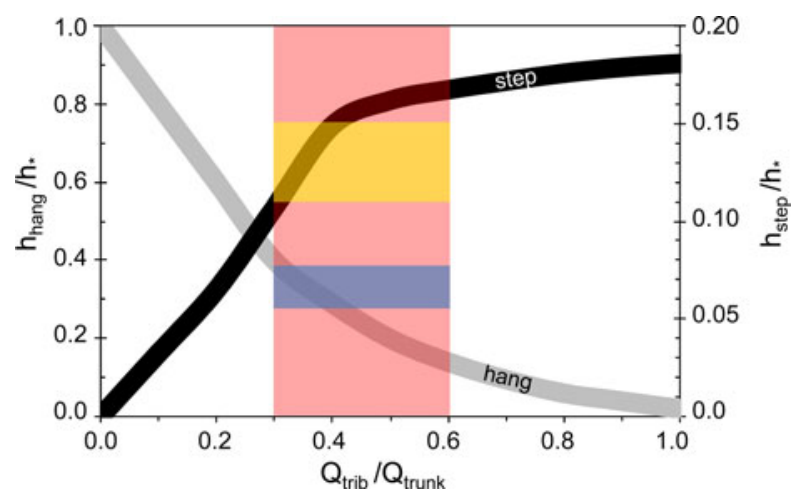

Fig. 10. Relative flux of a tributary and trunk $\left(Q_{\text {trib }} / Q_{\text {trunk }}\right)$ related to the normalised heights of the tributary's hanging valley $\left(h_{\text {hang }} / h^{*}\right)$ and the bedrock step at the tributary-trunk junction $\left(h_{\text {step }} / h^{*}\right)$. Thick grey lines are from the model output by MacGregor and others (2000). For Shackleton Glacier $Q_{\text {trib }} / Q_{\text {trunk }}$ is $0.3-0.6$ (red zone; see Table 3$), h_{\text {hang }} / h^{*}$ is $0.28-0.38$ (blue zone) and $h_{\text {step }} / h^{*}$ is $0.11-0.15$ (yellow zone). Modified from: MacGregor and others (2000).

Following MacGregor and others (2000), we normalise the bedrock step and hanging valley heights relative to the depth of the trunk valley erosion immediately upstream of the junction. We estimate this depth to be $\sim 1350 \mathrm{~m}$, based on ice thickness given by the difference in elevation between the maximum height of the Cordilleran Ice Sheet around the Last Glacial Maximum at this location $(3000 \mathrm{~m}$ a.s.I.: Jackson and Clague, 1991; Seguinot and others, 2016) and the inferred bedrock floor elevation of the current trunk valley (i.e. current glacier surface elevation of $1900 \mathrm{~m}$ a.s.l. minus the ice thickness of 200, 250, or $300 \mathrm{~m}$ (see Table 1). In Figure 10 we plot our results for the range of relative fluxes (0.3-0.6: red zone) and the ranges of normalised step (0.11-0.15: yellow zone) and hanging valley heights (0.28-0.38: blue zone). Although our conclusions are somewhat hampered by the lack of depth measurements, our estimates are similar to ranges modelled by MacGregor and others (2000) and within the envelope of measured step heights versus flux ratio proxies by Amundson and Iverson (2006). From these results we conclude that bedrock step height relative to hanging valley height is indeed related to $Q_{\text {trib }} / Q_{\text {trunk }}$.

While bedrock erosion rates are chiefly determined by long-term ice discharge and thermal regime, local irregularities along glacier beds may also arise from spatial variation in bedrock lithology, tectonic structures and subglacial sediment storage (Hallet and others, 1996; Riihimaki and others, 2005; Dühnforth and others, 2010; Headley and others, 2012; Yanites and Ehlers, 2016). Hooke (1991) postulated that these local irregularities may translate as crevasse zones in glaciers, which can act to focus melt to the bed, concentrating the process of quarrying. As discussed in Section 2, neither lithology nor structural geology have likely contributed to enhancing the bedrock step in Shackleton Glacier; the step can therefore be primarily attributed to increased ice discharge below the tributary confluence, with enhanced quarrying once the icefall formed.

\subsection{Under what conditions may tributary/trunk interaction be conducive to surging behaviour?}

Based on our results and past observations (Section 1B), we hypothesise that flow restriction by a tributary of a surgetype glacier most likely occurs where the tributary flux is at least one third of the trunk flux $\left(Q_{\text {trib }} / Q_{\text {trunk }}>0.3\right)$ and where no icefall occurs at the confluence. Figure 11 presents a conceptual model illustrating that these conditions may occur where no substantial bedrock step has formed directly below a tributary-junction, or where a trunk glacier is thick enough to equilibrate the surface slope over a bedrock step.

Since MacGregor and others (2000) postulate that $Q_{\text {trib }} /$ $Q_{\text {trunk }}>0.3$ likely results in a significant bedrock step, we hypothesise that trunk restriction by a tributary in surgetype glaciers may only occur in situations where subglacial erosion is reduced or where structural controls prevent step formation. Reduced glacial erosive power occurs in cold to polythermal glaciers, slower flowing and small glaciers, in mountain ranges that have been recently glaciated, at low/ reverse bed slopes or overdeepenings, and in glacier systems with either very little basal debris or underlain by a till layer of substantial thickness (Hooke, 1991; Alley and others, 1997; Flowers and others, 2011; Jaeger and Koppes, 2016). Several of these are indicative of reduced subglacial drainage, which prevents flushing of sediments necessary to expose bedrock to erosion by ice (Hooke, 1991; Alley and others, 1997; Swift and others, 2002), and leads to weak subglacial water pressure fluctuations reducing sliding (Iken, 1981; Herman and others, 2011). Inefficient subglacial drainage in overdeepenings decreases erosion due to till layer retention and topographic ice flow resistance (Hooke, 1991; Alley and others, 1997; Flowers and others, 2011). Bedrock step formation may therefore also be

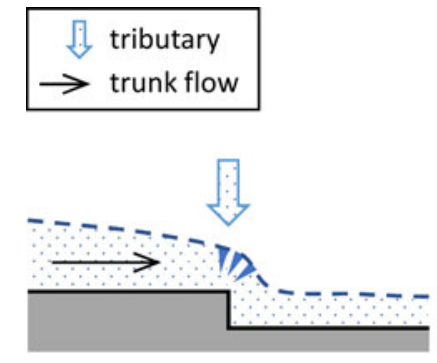

Large step + Icefall No restriction

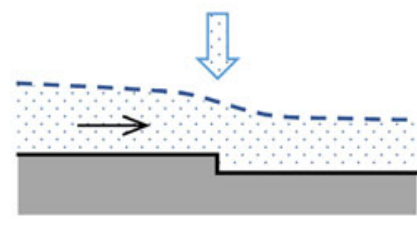

Reduced step height Restriction possible

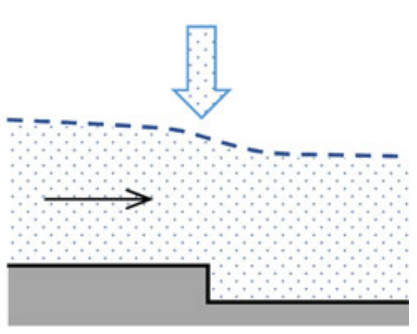

Thicker trunk + Larger tributary Restriction possible

Fig. 11. Conceptual model for flow restriction by a tributary of a surge-type glacier trunk. Left panel shows no restriction. In the middle and right panels restriction may occur due to reduced step height or thicker trunk glacier ice, respectively. The size of the tributary arrow corresponds to the relative tributary size. The size of the trunk flow arrow corresponds to the relative trunk flow speed. 
restricted if a tributary enters at the adverse bed slope part of a trunk overdeepening. We suggest an alternative explanation may hold as well, namely that tectonically active regions with an abundance of normal faulting, weaker bedrock, and high uplift and exhumation rates (Ring and others, 1999; Headley and others, 2012), may produce a till layer protecting underlying bedrock from erosion, providing this occurs while maintaining a regular (low) catchment gradient. Steeper catchments, often associated with tectonically active regions, permit more efficient subglacial drainage and therefore more efficient flushing of eroded sediment (Cook and Swift, 2012).

The specific configurations of dendritic surge-type glacier systems suggested here somewhat support the geological and climatic controls that have long been thought to relate to the non-uniform geographic distribution of surge-type glaciers (Post, 1969; Clarke and others, 1986; Jiskoot and others, 2003; Sevestre and Benn, 2015; Crompton and Flowers, 2016). Many surge-type glacier clusters occur in tectonically-active mountain ranges undergoing rapid erosion (Post, 1969; Copland and others, 2009), which corroborates that soft deformable beds may be a prerequisite for surging behaviour (Harrison and Post, 2003). However, the geometric and geological configurations may deviate from what we suggest here in dendritic surge-type glaciers with 'contagious' surges, where surges of tributaries can be triggered by a surge in the trunk glacier or vice versa (Harrison, 1964; Clarke and others, 1986; Glazovskiy, 1996).

\section{SUMMARY AND CONCLUSIONS}

We presented measurements of complex ice flow and related structural glaciology in a dendritic glacier with multiple icefalls in the Canadian Rockies, with a focus on flow at a tributary-trunk junction. Glacier-wide velocities vary from near zero to $65 \mathrm{~m} \mathrm{a}^{-1}$ in the trunk and up to $\sim 175 \mathrm{~m} \mathrm{a}^{-1}$ in icefalls. Structural glaciology, surface elevation and ice flow patterns reveal negative gradients in speed and associated compression above the tributary-trunk junction, but nearer the junction the trunk is funnelled and flow increases towards a downstream icefall related to a large bedrock step. In Shackleton Glacier, at this time, the tributary diverts the ice flow in the trunk, and no net outflow restriction takes place. Using our field data to estimate relative fluxes of the tributary and trunk flow units in the order of 0.3-0.6, we conclude that the erosion model by MacGregor and others (2000) uses a justifiable approximation of these relative fluxes to calculate the resulting relative normalised heights of the bedrock step and the hanging valley. It is the first time that an extant glacier is used to test such a model, and our observations support the model.

Our findings further suggest that once increased erosion at a tributary-trunk junction has resulted in a significant bedrock step, this step configuration may reduce a tributary's influence on the outflow of the trunk. This inference may be relevant for the understanding of tributary glacier outflow restrictions in surge-type glaciers. Based on our results, and common tributary configurations at surge-type glaciers worldwide, we hypothesise that only in geological and glacial erosive situations that prevent formation of large bedrock steps, may tributary/trunk interactions contribute to surge potential.

Further research into tributary-trunk confluence configurations may advance our understanding of controls on surging and improve models of tributary-trunk glacier surging, which have as yet only included simplified treatments (e.g. Oerlemans and van Pelt, 2015). As glaciers around the world continue to shrink, rates of glacier thinning, retreat and fragmentation may change the flow fields around tributary junctions. Thus, understanding the blocking potential of tributaries on their trunks will become increasingly important for predicting glacier run-off and sea-level rise.

\section{ACKNOWLEDGEMENTS}

Field assistants of the Shackleton Glacier expeditions are thanked for their hard work, during which Canadian Helicopters and Alpine Helicopters stationed in Golden provided helicopter support. We thank Parks Canada (particularly Darrel Zell) for providing access to Radarsat-2 data through the Government of Canada Allocation, administered by the Canadian Space Agency. Mark Mueller assisted with GIS, Gaëlle Gilson with Matlab, Shawn Bubel advised on surveying equipment and Matt Nolan commented on an early draft. Two anonymous reviewers are thanked for their constructive comments. Research funding was to $\mathrm{HJ}$ through an NSERC Discovery Grant and University of Lethbridge Professional Supplement.

\section{REFERENCES}

Alley RB and 5 others (1997) How glaciers entrain and transport basal sediment: physical constraints. Quat. Sci. Rev., 16(9), 1017-1038

Amundson JM and Iverson NR (2006) Testing a glacial erosion rule using hang heights of hanging valleys, Jasper National Park, Alberta, Canada. J. Geophys. Res., 111, F01020 (doi: 10.1029/ 2005JF000359)

Anderson RS, Molnar P and Kessler MA (2006) Features of glacial valley profiles simply explained. J. Geophys. Res., 111, F01004 (doi: 10.1029/2005JF000344)

Anderton PW (1973) Structural glaciology of a glacier confluence, Kaskawulsh Glacier, Yukon Territory, Canada. Institute of Polar Studies, Report \# 26. The Ohio State University, 108 pp

Clarke GKC, Collins SG and Thompson DE (1984) Flow, thermal structure, and subglacial conditions of a surge-type glacier. Can. J. Earth Sci., 21, 232-240

Clarke GKC, Schmok JP, Ommanney CSL and Collins SG (1986). Characteristics of surge-type glaciers. J. Geophys. Res., 91(B7), 7165-7180

Clarke GKC, Jarosch AH, Anslow FS, Radić V and Menounos B (2015) Projected deglaciation of western Canada in the twentyfirst century. Nat. Geosci., 8(5), 372-377

Colgan W and 6 others (2016). Glacier crevasses: observations, models and mass balance implications. Rev. Geophys., 54(1), 119-161

Cook SJ and Swift DA (2012). Subglacial basins: their origin and importance in glacial systems and landscapes. Earth-Sci. Rev., 115(4), 332-372

Copland L and 8 others (2009) Glacier velocities across the central Karakoram. Ann. Glaciol., 50(52), 41-49

Crompton JW and Flowers GE (2016) Correlations of suspended sediment size with bedrock lithology and glacier dynamics. Ann. Glaciol., 57(72), 142-150

Cuffey KM and Paterson WSB (2010) The physics of glaciers, 4th edn. Butterworth-Heinemann, Oxford

Davis JL, Halliday JS and Miller KJ (1973) Radio echo sounding on a valley glacier in east Greenland. J. Glaciol., 12(64), 87-91

Dühnforth M, Anderson RS, Ward D and Stock GM (2010) Bedrock fracture control of glacial erosion processes and rates. Geology, 38(5), 423-426 
Eyles N and Rogerson RJ (1977) Glacier movement, ice structures, and medial moraine form at a glacier confluence, Berendon Glacier, British Columbia, Canada. Can. J. Earth Sci., 14(12), 2807-2816

Fatland DR, Lingle CG and Truffer M (2003) A surface motion survey of Black Rapids Glacier, Alaska, U.S.A. Ann. Glaciol., 36, 29-36

Flowers GE, Roux N and Pimentel S (2011) Present dynamics and future prognosis of a slowly surging glacier. Cryosphere, 5, 299-313

Glasser NF, Hambrey MJ, Crawford KR, Bennett MR and Huddart D (1998) The structural glaciology of Kongsvegen, Svalbard, and its role in landform genesis. J. Glaciol., 44(146), 136-148

Glazovskiy AF (1996) The problem of surge-type glaciers. In Kotlyakov VM ed. Variations of snow and ice in the past and at present on a global and regional scale. IHP-IV Project H-4.1, UNESCO, $78 \mathrm{pp}$

Gudmundsson GH (1999) A three-dimensional numerical model of the confluence area of Unteraargletscher, Bernese Alps, Switzerland. J. Glaciol., 45(150), 219-230

Gudmundsson GH, Funk M and Iken A (1997) Measurements of ice deformation at the confluence area of Unteraargletscher Bernese Alps, Switzerland. J. Glaciol., 43(145), 548-556

Hallet B, Hunter L and Bogen J (1996) Rates of erosion and sediment evacuation by glaciers: a review of field data and their implications. Glob. Planet. Change, 12(1-4), 213-235

Hambrey MJ and Lawson W (2000) Structural styles and deformation fields in glaciers: a review. Geol. Soc. Spec. Publ., 176(1), 59-83

Hambrey MJ and Müller F (1978) Structures and ice deformation in the White glacier, Axel Heiberg Island, Northwest Territories, Canada. J. Glaciol., 20(82), 41-66

Harbor JM (1992) Numerical modelling of the development of U-shaped valleys by glacier erosion. Geol. Soc. Am. Bull., 104 (10), 1364-1375

Harrison AE (1964) Ice surges on the Muldrow Glacier, Alaska. l. Glaciol., 5, 365-368

Harrison WD and Post AS (2003) How much do we really know about glacier surging? Ann. Glaciol., 36(1), 1-6

Hattersley-Smith G (1969) Recent observations on the surging Otto Glacier, Ellesmere Island. Can. J. Earth Sci., 6(4), 883-889

Headley R, Hallet B, Roe G, Waddington ED and Rignot E (2012) Spatial distribution of glacial erosion rates in the St. Elias range, Alaska, inferred from a realistic model of glacier dynamics. J. Geophys. Res., 117, F03027 (doi:10.1029/2011JF002291)

Heinrichs TA, Mayo LR, Echelmeyer KA and Harrison WD (1996) Quiescent-phase evolution of a surge-type glacier: Black Rapids Glacier, Alaska, USA. J. Glaciol., 42(140), 110-122

Herman F, Beaud F, Champagnac JD, Lemieux JM and Sternai $P$ (2011) Glacial hydrology and erosion patterns: a mechanism for carving glacial valleys. Earth Planet. Sci. Lett., 310(3), 498-508

Hewitt K (2007). Tributary glacier surges: an exceptional concentration at Panmah Glacier, Karakoram Himalaya. J. Glaciol., 53 (181), 181-188

Hooke RL (1991) Positive feedbacks associated with erosion of glacial cirques and overdeepenings. Bull. Geol. Soc. Am., 103, 1104-1108

Iken A (1981) The effect of the subglacial water pressure on the sliding velocity of a glacier in an idealized numerical model. J. Glaciol., 27(97), 407-421

Jackson Jr LE and Clague JJ (1991) The Cordilleran Ice Sheet: one hundred and fifty years of exploration and discovery. Géogr. Phys. Quat., 45(3), 269-280

Jaeger JM and Koppes MN (2016) The role of the cryosphere in source-to-sink systems. Earth-Sci. Rev., 153, 43-76

Jiskoot $\mathrm{H}$ and Mueller MS (2012) Glacier fragmentation effects on surface energy balance and runoff: field measurements and distributed modelling. Hydrol. Process., 26(12), 1861-1875

Jiskoot H, Pedersen AK and Murray T (2001) Multi-model photogrammetric analysis of the 1990s surge of Sortebræ, East Greenland. J. Glaciol., 47(159), 677-687
Jiskoot H, Luckman A and Murray T (2003) Surge potential and drainage basin characteristics in East Greenland. Ann. Glaciol. 36, 142-148

Jiskoot H, Curran CJ, Tessler DL and Shenton LR (2009) Changes in Clemenceau Icefield and Chaba Group glaciers, Canada, related to hypsometry, tributary detachment, length-slope and areaaspect relations. Ann. Glaciol., 50(53), 133-143

Kargel JS and 16 others (2005) Multispectral imaging contributions to global land ice measurements from space. Remote Sens. Environ., 99(1), 187-219

King O, Hambrey MJ, Irvine-Fynn TD and Holt TO (2015) The structural, geometric and volumetric changes of a polythermal Arctic glacier during a surge cycle: Comfortlessbreen, Svalbard. Earth Surf. Process. Landf., 41(2), 162-177

Kotlyakov VM, Osipova GB and Tsvetkov DG (2008) Monitoring surging glaciers of the Pamirs, central Asia, from space. Ann. Glaciol., 48, 125-134

Lawson WJ, Sharp MJ and Hambrey MJ (2000) Deformation histories and structural assemblages of glacier ice in a non-steady flow regime. Geol. Soc. Spec. Publ., 176(1), 85-96

Lewis WV (1947) Valley steps and glacial valley erosion. Trans. Inst. Br. Geogr., 13, 19-44

Lickorish WH (1993) Geology, Clemenceau Icefield (west half), British Columbia (82N/13W1/2), Geological Survey of Canada. Open File, scale 1:50 000

Lickorish WH and 6 others (1992) Geology, Wood Arm, Kootenay Land District, British Columbia, 1:50 000 Map 83/D1. Geological Survey of Canada, Open File 2513; 1 sheet (doi: 10.4095/133387)

Linsbauer A, Paul F and Haeberli W (2012) Modeling glacier thickness distribution and bed topography over entire mountain ranges with GlabTop: application of a fast and robust approach. J. Geophys. Res., 117, F03007 (doi: 10.1029/2011JF002313)

MacGregor KR, Anderson RS, Anderson SP and Waddington ED (2000) Numerical simulations of glacial-valley longitudinal profile evolution. Geology, 28(11), 1031-1034

Mattar KE and 5 others (1998) Validation of alpine glacier velocity measurements using ERS tandem-mission SAR data. IEEE Trans. Geosci. Remote Sens., 36(3), 974-984

Meier MF and Post A (1969) What are glacier surges? Can. J. Earth Sci., 6(4), 807-817

Meier MF, Kamb BW, Allen CR and Sharp RP (1974) Flow of Blue Glacier, Olympic Mountains, Washington, USA. J. Glaciol., 13 (68), 187-212

Moore PL, Iverson NR and Cohen D (2010) Conditions for thrust faulting in a glacier. J. Geophys. Res., 115, F02005 (doi: 10.1029/2009JF001307)

Murray T, and 6 others (2000) Glacier surge propagation by thermal evolution at the bed. J. Geophys. Res., 135(B6), 13491-13507

Nye JF (1952) The mechanics of glacier flow. J. Glaciol., 2(12), 82-93

Oerlemans J (1989) On the response of valley glaciers to climatic change. In Oerlemans J ed. Glacier fluctuations and climatic change. Springer, Netherlands, 353-371

Oerlemans J and van Pelt WJJ (2015) A model study of Abrahamsenbreen, a surging glacier in northern Spitsbergen. Cryosphere, 9(2), 767-779

Ommanney CSL (2002) Glaciers of the Canadian Rockies. In Ferrigno J and Williams Jr RS, eds. Satellite image atlas of glaciers of the world. Prof. Pap., 1386-J, U.S. Geol. Surv. 199-289

Paul F (2015) Revealing glacier flow and surge dynamics from animated satellite image sequences: examples from the Karakoram. Cryosphere, 9(6), 2201-2214

Penck A (1905) Glacial features in the surface of the Alps. J. Geol., 13, $1-19$

Post A (1969) Distribution of surging glaciers in western North America. J. Glaciol., 8(53), 229-240

Quincey DJ and 5 others (2009) Ice velocity and climate variations for Baltoro Glacier, Pakistan. J. Glaciol., 55(194), 1061-1071 
Raymond CF (1971). Flow in a transverse section of Athabasca Glacier, Alberta, Canada. J. Glaciol., 10(58), 55-84

Raymond CF (1987). How do glaciers surge? A review. J. Geophys. Res.: Solid Earth., 92(B9), 9121-9134

Riihimaki CA, MacGregor KR, Anderson RS, Anderson SP and Loso MG (2005) Sediment evacuation and glacial erosion rates at a small alpine glacier. J. Geophys. Res., 110, F03003 (doi: 10.1029/2004JF000189)

Ring U, Brandon MT, Willett SD and Lister GS (1999) Exhumation processes. Geol. Soc. Spec. Publ., 154(1), 1-27

Satyabala SP (2016) Spatiotemporal variations in surface velocity of the Gangotri glacier, Garhwal Himalaya, India: study using synthetic aperture radar data. Remote Sens. Environ., 181, 151-161

Seguinot J, Rogozhina I, Stroeven AP, Margold M and Kleman J (2016) Numerical simulations of the Cordilleran ice sheet through the last glacial cycle. Cryosphere, 10, 639-664

Sevestre H and Benn DI (2015) Climatic and geometric controls on the global distribution of surge-type glaciers: implications for a unifying model of surging. J. Glaciol., 61(228), 646-662

Shugar DH, Rabus BT and Clague JJ (2010) Elevation changes (1949-1995) of Black Rapids Glacier, Alaska, derived from a multi-baseline InSAR DEM and historical maps. J. Glaciol., 56 (198), 625-634
Swift DA, Nienow PW, Spedding N and Hoey TB (2002). Geomorphic implications of subglacial drainage configuration: rates of basal sediment evacuation controlled by seasonal drainage system evolution. Sediment. Geol., 149, 5-19

Tennant C, Menounos B, Wheate R and Clague JJ (2012) Area change of glaciers in the Canadian Rocky Mountains, 1919 to 2006. Cryosphere, 6(6), 1541-1552

Van der Veen CJ (1999) Crevasses on glaciers. Polar Geogr., 23(3), 213-245

Van Wychen W and 5 others (2012) Spatial and temporal variation of ice motion and ice flux from Devon Ice Cap, Nunavut, Canada. J. Glaciol., 58(210), 657-664

Van Wychen W and 6 others (2016) Characterizing interannual variability of glacier dynamics and dynamic discharge (1999-2015) for the ice masses of Ellesmere and Axel Heiberg Islands, Nunavut, Canada. J. Geophys. Res. Earth Surf., 121, 39-63 (doi: 10.1002/2015JF003708)

Voigt $U$ (1966) The determination of the direction of movement on glacier surfaces by terrestrial photogrammetry. J. Glaciol., 6(45), 359-367

Yanites BJ and Ehlers TA (2016) Intermittent glacial sliding velocities explain variations in long-timescale denudation. Earth Planet. Sci. Lett., 450, 52-61

MS received 24 March 2017 and accepted in revised form 23 August 2017 